ALBERT R. MANN LIBRARY

New York State Colleges

OF

Agriculture and Home Economics

AT

Cornell University

EVERETT FRANKLIN PHILLIPS

BEEKEEPING LIBRARY 


\section{STATE OF NEW JERSEY \\ DEPARTMENT OF AGRICULTURE \\ ALVA AGEH, Secretary}

\section{CIRCULAR}

Number 3

\section{DATE DUE}

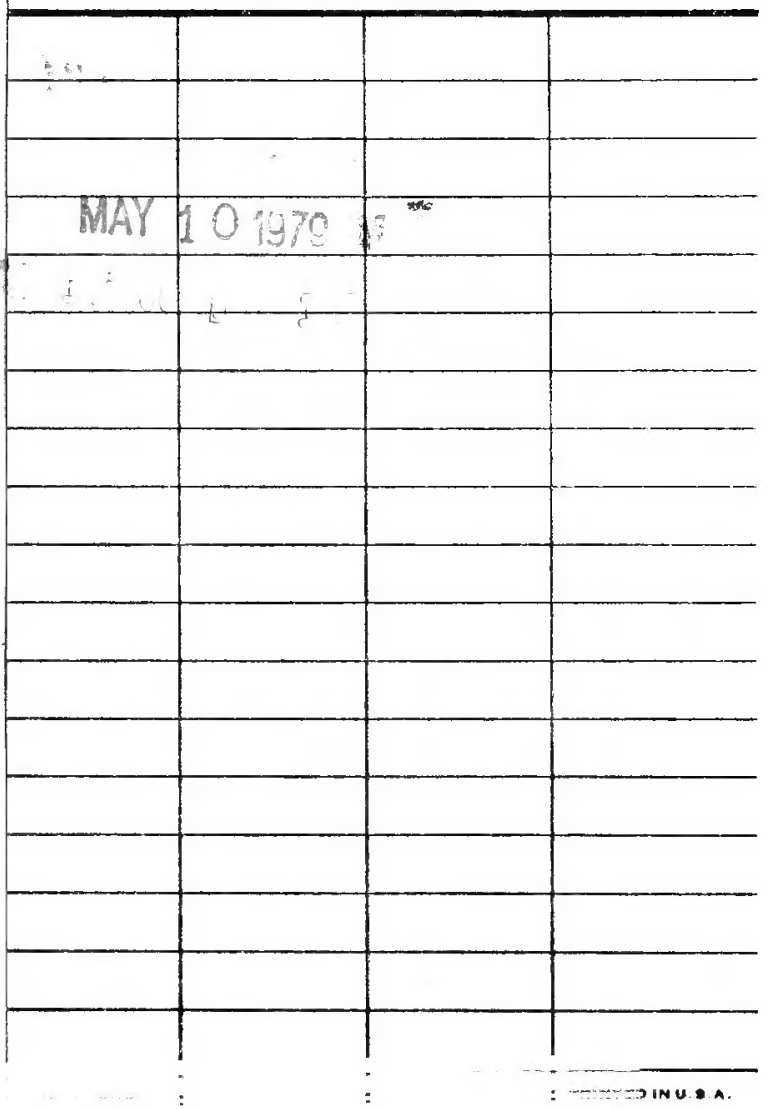




\section{31 \\ 0.28 \\ TABLE OF CONTENTS}

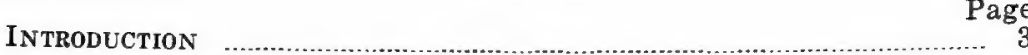

BeE DISEASE CONTROL

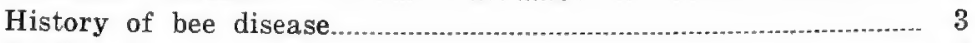

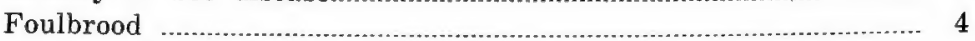

American foulbrood .................................................................... 4

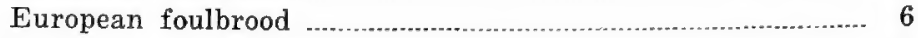

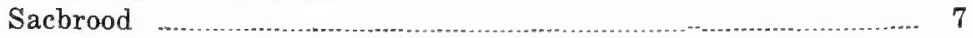

Brood diseases contrasted......................................................... 9

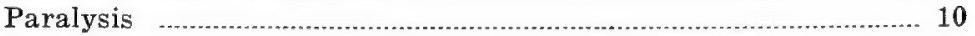

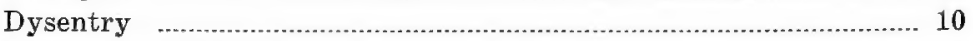

Control measures …............................................................... 10

American foulbrood ....................................................... 10

European foulbrood ............................................................... 12

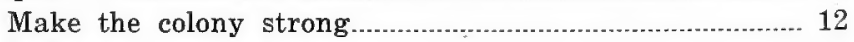

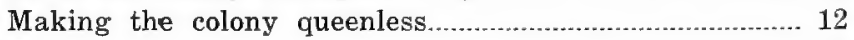

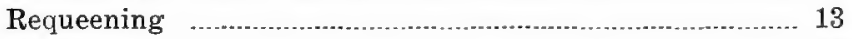

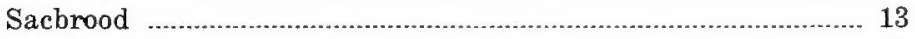

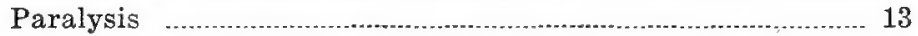

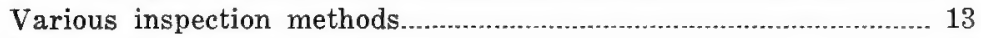

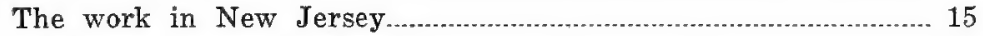

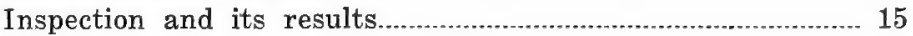

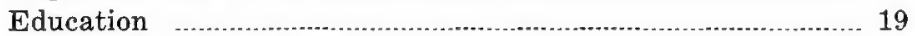

Educating the beekeepeer direct......................................... 19

Through the mails........................................................... 19

Through the farm demonstrator...................................... 20

Requirements and Possibilities of Beekeeping as a Business .....- 20

Requirements of profitable bee husbandry..................................... 20

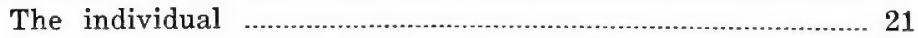

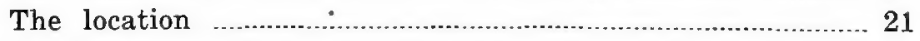

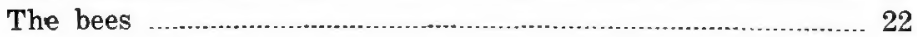

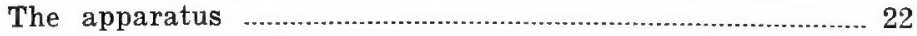

Returns from beekeeping .......................................................... 23

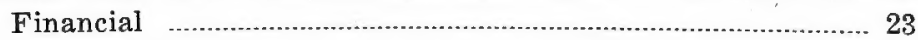

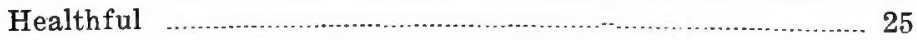

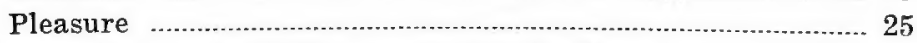

Opportunities for profitable beekeeping in New Jersey............... 26

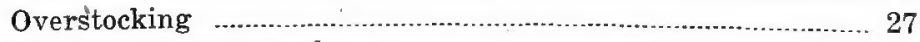

Market for increased crops................................................ 27

Beekeeping literature ............................................................ 28

Publications pertaining to beekeeping issued by the United

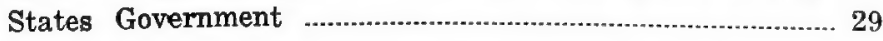




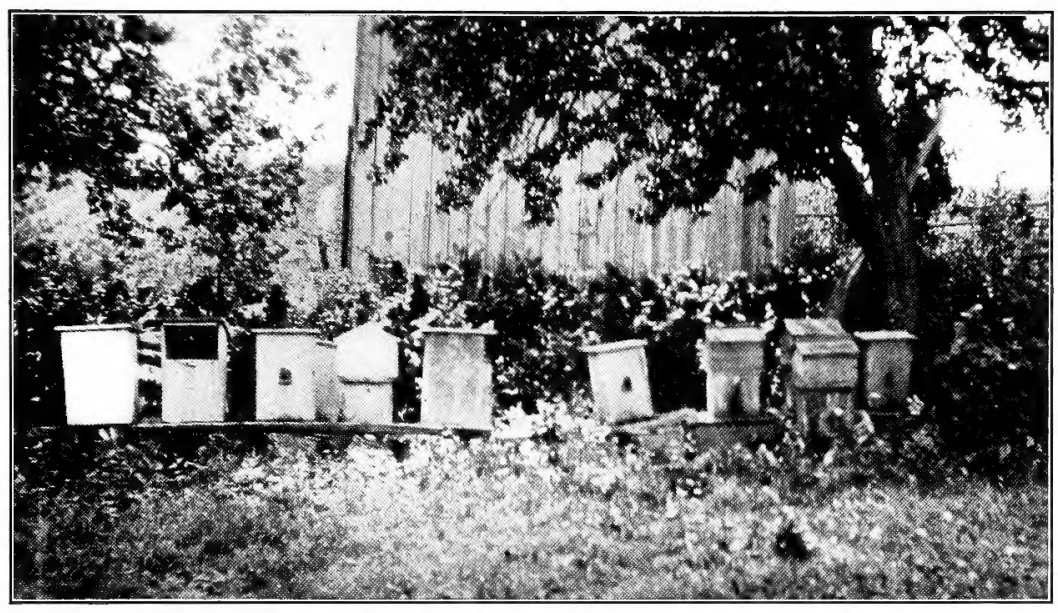

This New Jersey Apiary Gives an Annual Return of 75 Cents PER APtary.

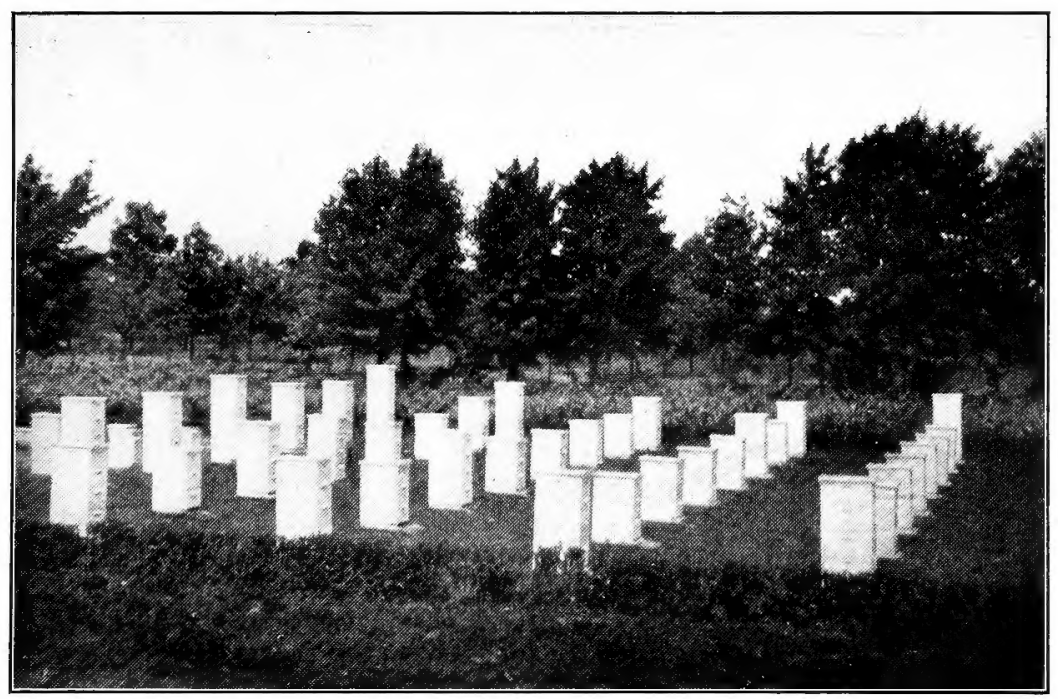

The Annual Return from this New Jersey Apiary is $\$ 7.00$ PER COLONY. 


\section{Cornell University Library}

The original of this book is in the Cornell University Library.

There are no known copyright restrictions in the United States on the use of the text. 


\title{
BEE DISEASE CONTROL
}

\author{
Elmer G. Carr \\ Deputy of the State Entomologist in Bee Inspection \\ New Jersey State Department of Agriculture
}

\section{INTRODUCTION}

Save for the annual report of the state entomologist which has had only a limited distribution, no effort has been made during the past four years to present to the people of New Jersey a statement of the progress in control of bee diseases, the advancement in the methods of fighting the diseases, and the possibilities of bee keeping as a business. Because of this lack of information, the Department of Agriculture has seen fit to authorize the publication of the following paper, in which the subjects mentioned are taken up.

The writer wishes to acknowledge his indebtedness to the state entomologist, Dr. Thomas J. Headlee, for helpful criticism and advice in the preparation of this circular.

BEE DISEASE CONTROL

\section{History of Bee Disease}

Every form of animal life is subject to disease, and in the economic animal forms the control of disease is necessary for their successful management. This is true of honey bees.

The exact date when it became known that bees have disease is not fixed. The difficulty in keeping a single adult bee under observation for any considerable length of time and the fact that they do not respond to efforts directed toward their domestication makes their study for disease difficult. Hives so constructed that every part can be readily examined have been in use but 
Missing Page 


\section{American Foulbrood}

The date when the differences in the two diseases were positively recognized is obscure, but the work of Dzierzon in 1882 is the first which appears at all reliable.

American foulbrood is an infectious disease of the larvæ of the honey bee, caused by Bacillus larve White. The majority of the larvæ are killed by this disease about the time they are normally sealed. For this reason the initial stages of the disease are seldom seen in a colony only recently attacked. As the disease progresses the larvæ lose their plump form and pearly white color, sink down in the cell and the color becomes at first a light brown, changing to a dark brown in the last stages of the disease. Finally, the dried down larva forms a scale on the lower side wall with the head toward the mouth of the cell and the posterior end slightly turned up against the cell base. These scales adhere tightly to the cell wall and are removed only with difficulty by the beekeeper and practically not at all by the bees.

There is a pronounced odor accompanying this disease which has been likened to that from poor glue when heated. It also resembles somewhat the odor from decaying animal skins. This odor while pronounced is usually not intense. If a comb containing advanced stages of this disease is removed from the hive and kept in a warm place, the odor increases for a time, then gradually becomes less.

The first symptoms which attract the apiarist's attention upon opening a hive infected with American foulbrood are the scattered appearance of the brood, and sunken and perforated cappings over the diseased brood. The disease causes death in the majority of cases after the larvæ are sealed. This is particularly true in a colony which has been infected a short time. The bees, finding the brood does not emerge as it should, make holes in the cappings varying in size from a mere perforation to the removal of the entire capping.

The color of the capping over diseased larvæ is darker than that covering healthy brood. The cappings become sunken and

\footnotetext{
${ }^{4}$ White, G. F. 1907. The cause of American foulbrood. U. S. Dept.
} Agr. Bur. Ent. Cir. 94. 
also look as though they were saturated with grease, whereas the cappings over healthy larvæ have a porous appearance somewhat resembling coarse paper.

At that stage of the progress of the disease, when the larva has sunk down in the cell, the color has become a pronounced brown and the larva is still moist. If a small stick is inserted in the dead larva and withdrawn, a part of the decaying mass will adhere to the stick and be drawn out in a thread sometimes several inches in length.

In the final stages of the disease the dried-down larvæ are found, with rare exceptions, on the lower cell wall.

In advanced cases many larvæ die before the sealing stage, but usually there are in such cases a sufficient number of the characteristic scales to make it evident that American foulbrood is the invader. Death sometimes does not occur until pupation has begun, and occasionally the dried-down pupa is found with the tongue extended across the mouth of the cell.

Usually only worker larvæ are attacked by this disease, although drone and queen larvæ are sometimes affected.

Contrary to experience with European foulbrood, American foulbrood shows no sharp increase or decrease in relation to any particular part of the active season, neither has there been found a race of bees which have shown definite resistance to its attacks.

In an apiary where this disease is present, usually a small percentage of colonies are found affected unless the disease has been much neglected. The spread of this disease in an infected colony is much slower than is the case in a colony infected with European foulbrood.

\section{European Foulbrood}

This form of foulbrood is caused by Bacillus pluton White ${ }^{5}$. The majority of the larvæ affected die before the time for sealing; in advanced cases, many do not get beyond the stage when they are curled up in the bottom of the cell. Some are sealed before death occurs. There is a loss of form of the larva. The 
color varies. It is sometimes gray, some specimens are a decided yellow, others have a yellow spot near the head and still others are light brown.

Eventually the dead larvæ dry down and form irregular scales, which may be found on any wall of the cell or on the base. These scales are not difficult of removal. The larvæ affected with this disease also exhibit this irregularity. Sometimes both ends of the larva will be toward the base of the cell or both toward the cell mouth. This irregularity of the position of diseased larvæ and scales is one of the most important symptoms in determining this disease.

The rotting larvæ present a jelly-like mass and when a stick is inserted and withdrawn there is rarely any pronounced ropiness, as in American foulbrood. In his description of this disease Phillips" says: "There is little or no odor to European foulbrood, but sometimes a sour odor is present, which reminds one of yeast fermentation." In the writer's experience the odor accompanying this disease, particularly in advanced cases, is often so intense as to be readily detected several feet from the diseased hive. There is nothing to which it can be readily likened, although there is a slight resemblance to the odor of earwax (cerumen). Sometimes this odor is slight and scarcely noticeable, even when the infected comb is held close to the face. This condition, however, is quite exceptional.

In the examination of over I,000 colonies infected with European foulbrood, the writer has found about six which did not have the characteristic odor so marked as to be easily recognized. Therefore, it would seem that the odor symptom is fairly constant under New Jersey conditions.

Diseased combs when removed from the hive lose their pronounced odor within a few days. This disease does most damage in the spring and early summer. Drone larvæ are attacked quite as readily as worker larvæ, and queen larvæ are also often affected.

Italian bees show a higher resistance to this disease than do blacks or hybrids. It is common to find a large percentage of

${ }^{6}$ Phillips, E. F., 1913. The treatment of bee diseases. U. S. Dept. Agr. Farmers' Bul. 442. 
colonies affected in an apiary where this disease is present, although this cannot be considered the rule. The symptoms of this disease are so variable that often close observation is necessary to determine which disease is present in the colony. This disease often works with great rapidity, entirely ruining the colony in one season.

\section{Sacbrood}

Another recognized disease affecting bee larvæ is known as sacbrood, formerly sometimes called "pickled brood." This disease, according to White ${ }^{i}$, is caused by "a filterable virus." It causes death in the larvæ in an advanced stage of their development, usually at or immediately after the time of sealing. Often a slight discoloration is noticed in the cappings covering larvæ which have died of this disease. Perforated cappings are seen but seldom. Apparently the bees entirely remove the capping at one operation.

The dead larvæ are found on the lower cell wall, the head outward, usually pointed and slightly turned upward away from the lower cell wall.

The color is brownish gray to a dirty grayish brown. The head is darker than the body, often being nearly black in color. When dried the dead larva forms a scale which is removable without the least difficulty.

Practically no odor accompanies this disease, although if a punctured larva is held close to the face a slight yeasty odor is noticed. The larval skin does not decay as readily as the body contents, but remains unbroken, and by careful manipulations the larva can be removed from the cell entire. The body contents are watery. The dead larvæ show no ropiness whatever. This disease does not usually cause a high mortality, and it is extremely rare to find a colony of bees in New Jersey so badly affected as to cause appreciable loss. 'White, G. F., 1913. Sacbrood, a disease of bees. U. S. Dept. Agr.
Bur. Ent. Cir. 169. 
Bee Disease Control

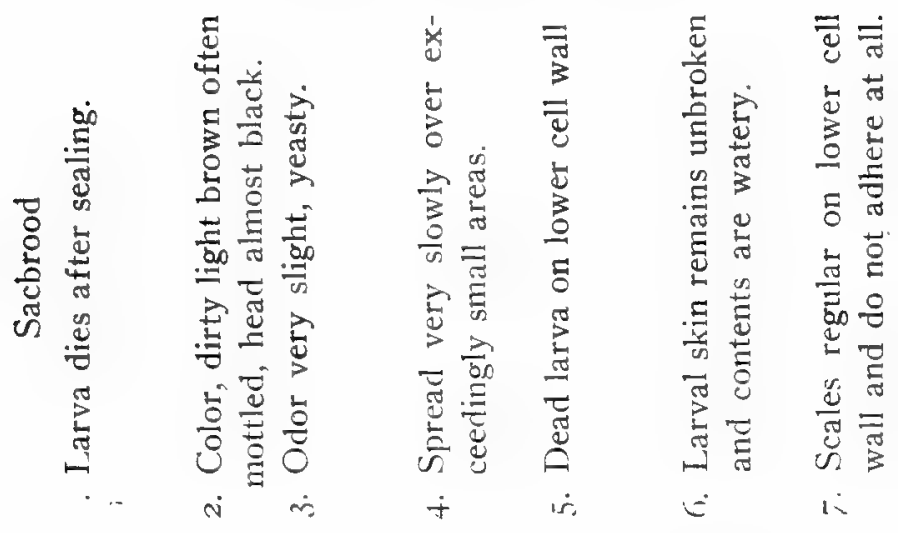

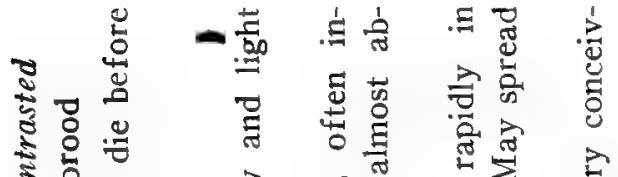

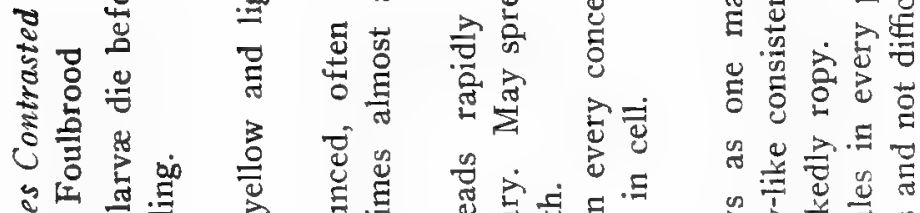

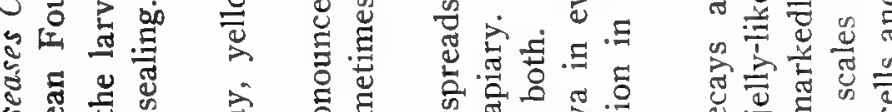

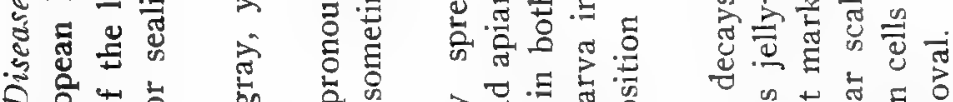

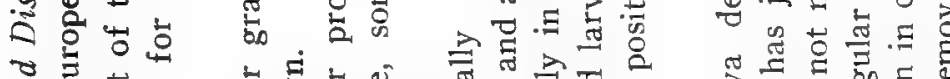

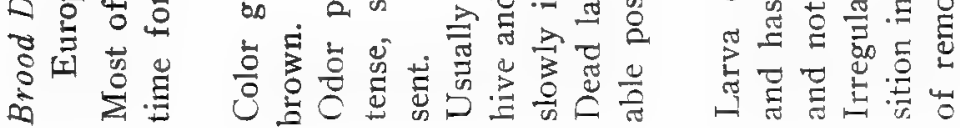

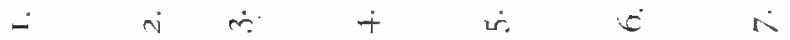

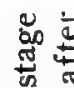

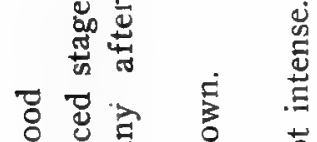

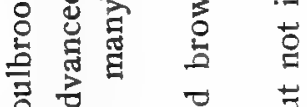

일

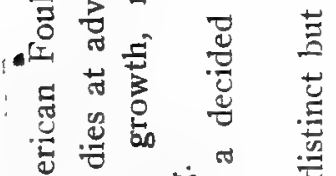

$\therefore \stackrel{\Xi}{\Xi}$

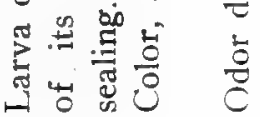

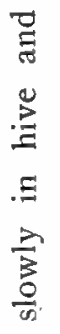

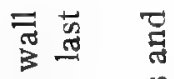

言零蚂

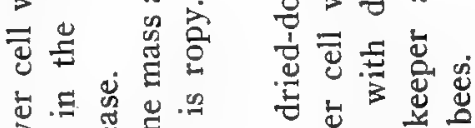

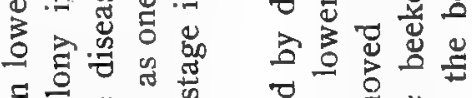

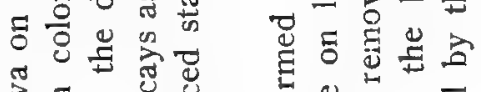

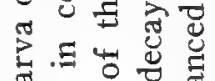

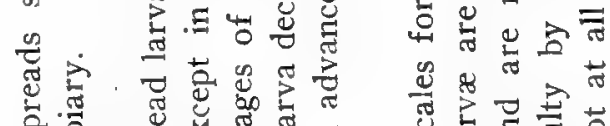

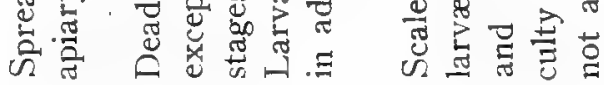
$\dot{\mathrm{j}}$

$\dot{5}$

ri 


\section{Paralysis}

This is a disease which affects the adult bees. When a colony of bees is attacked by this disease great numbers of the dead and dying are seen immediately in front of the hive. Many are seen feebly crawling about and crawling up blades of grass or other elevated objects and, attempting to fly, they fall to the ground. A majority have the abdomen considerably swollen. Many are almost hairless. A considerable number show a peculiar trembling movement. Upon opening the hive many bees are seen almost entirely devoid of hair. Seldom does this trouble cause the death of a colony although often the colony is so weakened as to be of no use as a producer of surplus honey. It is rare to find more than one or two colonies even in an apiary of considerable size affected with this disease. No cause has been assigned for this malady and there is no evidence to show that it is either contagious or infectious.

\section{Dysentery}

This is a disease of the adult bees which is manifested by the bees spotting the hive with their excrement It occurs in late winter or early spring and is caused by too long a confinement on unsuitable stores. Any stores which contain a large percentage of indigestible matter will bring on this trouble if the bees use such poor stores at a time when they cannot take cleansing flights.

\section{Control Measures}

\section{American Foulbrood}

There has not been discovered as yet any method of curing American foulbrood and at the same time saving the combs. This is because the bees are unable to remove from the cells the scales caused by the dried-down larva. These scales are full of the spores of the disease and their destruction by heat is the only known method for their elimination.

The process for curing a colony infected with American foulbrood is known as the shaking treatment. The bees are shaken or brushed from the diseased combs into a clean hive on the old 
stand. This hive is furnished with frames containing starters of foundation. The old hive is disinfected by scorching with fire, the wax rendered from the combs and the frames disinfected by boiling or destroyed by burning. If sufficient honey is in the diseased combs to make it worth while, it may be extracted and used for household purposes or it may be fed back to the bees after being diluted with an equal amount of water and heated sufficiently to kill the spores of disease which it contains. The heat necessary to render the combs makes the wax safe for further use by bees. White $8^{\circ}$ has shown that a temperature of $210^{\circ} \mathrm{F}$. for ten minutes is sufficient to kill the spores of this disease.

If considerable healthy brood is in the combs' and a number of colonies are to be treated, the hives of beeless combs may be placed above an excluder over a weak colony and at the end of ro days, when practically all the good brood has emerged, this colony may be shaken and the combs rendered. This is best done at the beginning of a honey flow.

If a considerable number of colonies are to be treated it will be found best to do the work in the middle of the day, taking every precaution to prevent the spread of the disease by robbing. If only one or two colonies need treatment, it is best done just before nightfall. In any case, to guard against absconding it is advisable to place an entrance guard, drone trap or perforated zinc before the hive entrance in such a manner that the queen is confined in the hive.

If the disease is not discovered until the season is well advanced and no further honey flow can reasonably be expected, one of two courses is open to the beekeeper. He can, if the disease has not reached a stage when destruction of the colony is advisable, leave it until broodrearing has ceased and shake the bees onto combs entirely full of honey free from disease. Or he can shake the bees onto foundation and feed sugar syrup to enable them to build and stock the combs. This latter process will not be found profitable.

It is much better, however, to treat a diseased colony late in the

8 White, G. F., 1914. Destruction of germs of infectious bee diseases by heating. U. S. Dept. Agr. Bul, 92. 
fall and fail to bring it through the winter alive than to leave it and have it die in the winter. The hive would thus be robbed out by other bees and the disease probably spread all through the apiary and possibly to neighboring apiaries.

Honey disinfected by heating must not be fed to bees at a time when it will be stored for winter use. Such stores will cause the death of the colony by dysentery

\section{European Foulbrood}

Formerly the same treatment was recommended for this form of foulbrood as for American foulbrood.

Within the last few years much work has been done on a modified treatment, and saving the combs of a colony infected with this disease is now possible, provided the disease has not reached the last stages, and provided further that all the conditions are met. The possibility of success with this modified treatment is remote unless good Italian bees are used.

Three conditions are necessary to succeed with this modified treatment. First, the colony must be strong; second, it must be without a laying queen for a period of time; third, it must be given an Italian queen of good stock.

Make the Colony Strong.-Definite strength of colony is not easily measured, but estimating the strength by the amount of brood and the number of frames covered by bees is sufficiently accurate. Figuring on the basis of the common L-size frame $(9 \mathrm{I} / 8 \times 175 / 8$ inches), the colony should have no less than 5 frames well filled with brood and enough bees to cover 6 frames. A deficiency should be made up by adding frames of emerging brood from healthy colonies or by uniting two or more diseased colonies. If it is desired to add bees only to the colony, frames of bees from healthy colonies, which can spare bees without being harmed, may be shaken in front of the colony to be strengthened. The old bees fly back to their hive and the young bees enter the hive in front of which they are shaken. The addition of young bees is important since young bees are the most active in cleaning out the cells, and this is the work needed at this time. 
Making the Colony Queenless.-It is necessary to check broodrearing for a sufficient time to give the bees an opportunity to clean out the diseased material This is done by removing or caging the reigning queen within the hive. This time will vary, depending on the amount of infection and the activity of the bees in cleaning out diseased material. Some colonies will be able to do the work in Io days and others may need to be kept queenless for " 3 weeks. Practically all the diseased larvæ should be cleaned out before the new queen which is to be given commences to deposit eggs. If the infection is very light and the queen is considered excellent, caging the queen in the hive will often prove successful. Killing the queen is considered best by the writer.

Requeening.-Best results will be obtained if a queen cell reared from good Italian stock is introduced containing a queen about to emerge. The period of preparation between the emergence of a young queen in the hive and the time she deposits eggs appears to be beneficial because under these conditions the bees display more activity in cleaning the cells for the reception of eggs. A laying queen may be used if a satisfactory ripe queen cell cannot be had.

Occasionally satisfactory results will be secured if a large swarm is hived in a colony infected with European foulbrood after first killing the queen in the hive. This disease sometimes disappears during a heavy honey flow; especially is this true if the honey flow comes in the autumn.

\section{Sacbrood}

No case of this disease has come under the writer's observation where any appreciable damage was being done to the infccted colony. The greatest infection would probably not exceed I5O cells in a single colony Believing that bees which become infected with sacbrood have a weakness which makes them susceptible to this disease, requeening is recommended in pronounced cases. 


\section{Paralysis}

The cause of this disease has not been discovered and no positive remedy is known. Recommended treatments are: sprinkling powdered sulphur on top of the frames; moving the infected colony to the stand of a healthy one; and requeening. Fortunately, this disease is not causing much trouble in New Jersey.

\section{Various Inspection Methods}

Bee disease control work in the various states is in charge of various officials, depending on the agricultural organization of the state. In some states the work is under the direct control of the governor, who appoints the deputy inspectors and to whom they report.

The state entomologist is the supervising officer in a number of states. Other supervisors are the state board of agriculture, the commissioner of agriculture, the state entomological commission, the economic zoologist, the state horticultural inspector, the board of supervisors, the agricultural commission, the county commissions and the county judge. Of all these various plans none appears to give results equal to that where the work is under the supervision of the state entomologist.

The delay in enacting bee disease control measures in New Jersey gave opportunity to observe the working of the various plans in other states and to plan a measure which appeared to have the most desirable features. The bee disease control in this State is in charge of the state entomologist. The field work is done by a deputy appointed by the Department of Agriculture upon the recommendation of the state entomologist after having been certified by the Civil Service Commission.

About the last week in April the field work is commenced and it usually ends the latter part of September. This time may be shortened by a late spring or an early autumn. In the past five years some work has been done in each of the $2 \mathrm{I}$ counties and a few of them have been quite thoroughly covered. Requests for inspection are given prompt attention. 


\section{The Work In New Jersey}

Inspection and Its Results

The result of inspection in the State as a whole will be seen in Table $\mathrm{I}$.

\section{TABLE I}

Summary of Apiary Inspection in New Jersey 1912-1916

\begin{tabular}{c|c|c|c|c|c|c}
\hline Year & $\begin{array}{c}\text { No. } \\
\text { Yards }\end{array}$ & $\begin{array}{c}\text { No. } \\
\text { Colonies }\end{array}$ & $\begin{array}{c}\text { No. } \\
\text { Boxes }\end{array}$ & $\begin{array}{c}\text { No. } \\
\text { Hives }\end{array}$ & $\begin{array}{c}\text { Colonies } \\
\text { Infected } \\
\text { with } \\
\text { American } \\
\text { Foulbrood }\end{array}$ & $\begin{array}{c}\text { Colonies } \\
\text { Infected } \\
\text { with } \\
\text { European } \\
\text { Foulbrood }\end{array}$ \\
\hline 1912 & 378 & 3227 & 355 & 2922 & 157 & 391 \\
1913 & 327 & 2932 & 606 & 2326 & 81 & 238 \\
1914 & 405 & 4001 & 802 & 3199 & 61 & 147 \\
1915 & 247 & 2460 & 446 & 2014 & 63 & 95 \\
1916 & 276 & 3227 & 598 & 2629 & 50 & 199 \\
\hline
\end{tabular}

Attention is called to the fact that of the 15,847 colonies inspected during the past five years, 2,807 , or more than one-fifth, were in boxes, kegs, etc., and hence the ordinary manipulations necessary for honey production or disease control were much restricted, if not entirely impossible. The proportion of American to European foulbrood holds at about the ratio of $I$ to 3 . There is noted a steady decrease in the number of colonies found with disease, both American and European, with the exception that there is an increase in the number of colonies with European foulbrood for 1916. This was caused by a serious outbreak of the disease at two points in Atlantic County which heretofore had been entirely free from disease.

This outbreak was not discovered until much damage had been done. The damage was made possible because (I) the majority of the hives used were of the immovable frame type and it was extremely difficult to learn the condition of the brood in them, and (2) the beekeepers were not practicing modern methods of bee management. With proper management, which includes Italian queens and movable frame hives, this damage could have been 
reduced to such an extent that no colonies would have been lost and the honey crop would not have been greatly reduced.

Another encouraging, as well as interesting, fact is brought out by the table, namely, that the number of colonies per apiary is increasing. In I9I2 the average was 8.5 colonies per apiary, while in 1916 the number was II.6. This is encouraging because more bees are needed in the State to gather the tons of nectar which now annually go to waste, and further, the larger the apiaries the greater will be the care given since the investment is greater and the beekeeper is more inclined to protect his investment.

\section{TABLE II}

Diseased Colonie in Three Counties in New Jersey Salem County

\begin{tabular}{|c|c|c|c|c|c|c|c|c|c|c|c|c|c|c|}
\hline \multirow{2}{*}{ Year } & \multirow{2}{*}{$\begin{array}{c}\text { No. } \\
\text { Yards }\end{array}$} & \multicolumn{3}{|c|}{$\begin{array}{c}\text { Yards } \\
\text { Diseased }\end{array}$} & \multicolumn{3}{|c|}{$\begin{array}{l}\text { Per Cent } \\
\text { Diseased }\end{array}$} & \multirow{2}{*}{$\begin{array}{l}\text { No. } \\
\text { Colo- } \\
\text { nies }\end{array}$} & \multicolumn{3}{|c|}{$\begin{array}{l}\text { Colonies } \\
\text { Diseased }\end{array}$} & \multicolumn{3}{|c|}{$\begin{array}{l}\text { Per Cent } \\
\text { Diseased }\end{array}$} \\
\hline & & E. & A. 17 & $\overline{\text { otal }}$ & E. & A. & Total & & E. & A. & Total & E. & A. & Total \\
\hline 1913 & 45 & 7 & 5 & $11^{*}$ & 15.5 & 11.1 & 24.4 & 353 & 21 & 12 & 33 & 5.9 & 3.3 & 9.3 \\
\hline 1915 & 35 & 7 & 0 & 7 & 20.0 & 0 & 20.0 & 509 & 13 & 0 & 13 & 2.5 & 0 & 2.5 \\
\hline \multicolumn{15}{|c|}{ Cumberland County } \\
\hline 1913 & 44 & 13 & 0 & 13 & 29.6 & 0 & 29.6 & 273 & 46 & 0 & 46 & 16.9 & 0 & 16.9 \\
\hline 1915 & 40 & 11 & 0 & 11 & 27.5 & 0 & 27.5 & 297 & 30 & 0 & 30 & 10.1 & 0 & 10.1 \\
\hline
\end{tabular}

Cape May County

\begin{tabular}{r|r|r|r|r|r|r|r|r|r|r|r|r|r|r}
\hline 1913 & 40 & 19 & 0 & 19 & 47.5 & 0 & 47.5 & 210 & 73 & 0 & 73 & 34.7 & 0 & 34.7 \\
1915 & 56 & 16 & 0 & 16 & 28.6 & 0 & 28.6 & 330 & 28 & 0 & 28 & 8.4 & 0 & 8.4 \\
\hline
\end{tabular}

Total for. Three Counties

\begin{tabular}{r|r|r|r|r|r|r|r|r|r|r|r|r|r|r}
\hline 1913 & 129 & 39 & 5 & $43 *$ & 30.2 & 3.8 & 34.1 & 836 & 140 & 12 & 152 & 16.7 & 1.4 & 18.1 \\
1915 & 131 & 34 & 0 & 34 & 25.9 & 0 & 25.9 & 1136 & 71 & 0 & 71 & 6.2 & 0 & 6.2 \\
\hline
\end{tabular}

*Both American and European foulbrood were found in one apiary. E-European foulbrood.

A-American foulbrood. 


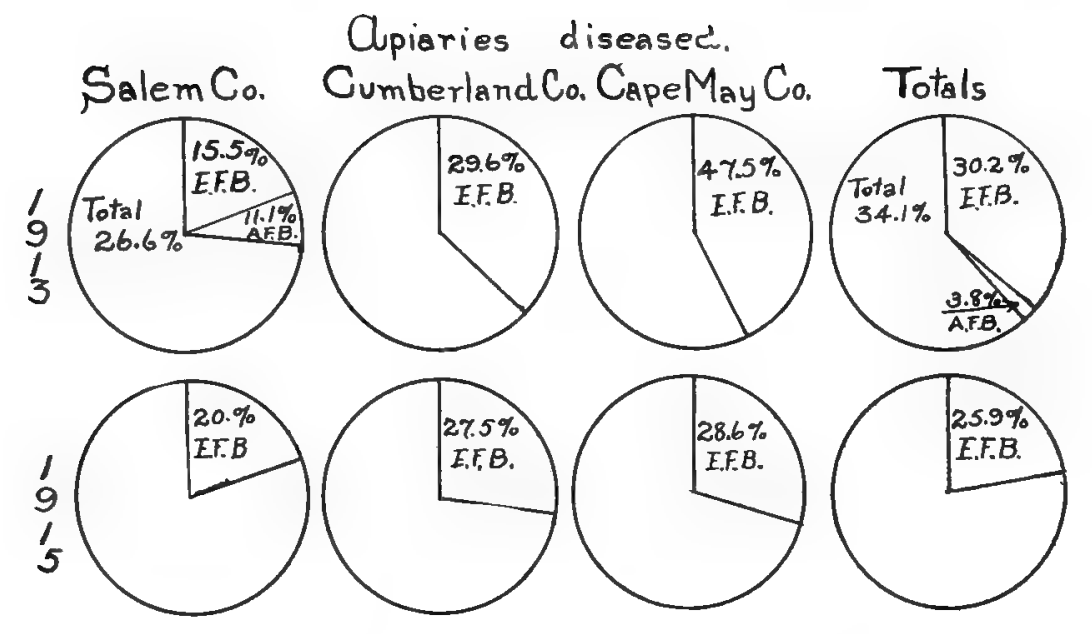

Colonies diseased.
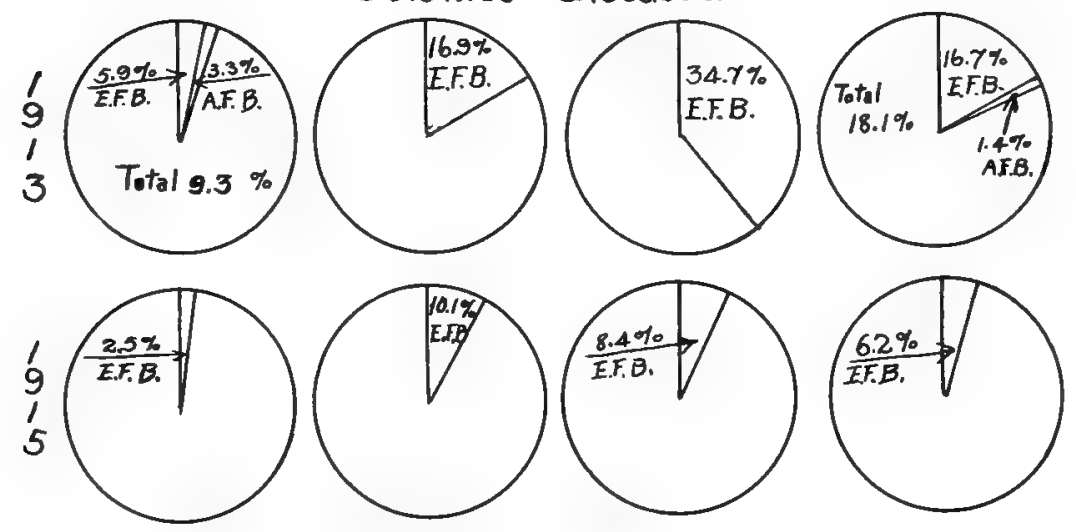

E.F.B - European foulbrood. A.F. $B .=$ American foulbrood.

Fig. I.-Diagrams showing Percentages of Diseased Apiaries and Colonies Found in New Jersey, 19iz-igi6. 


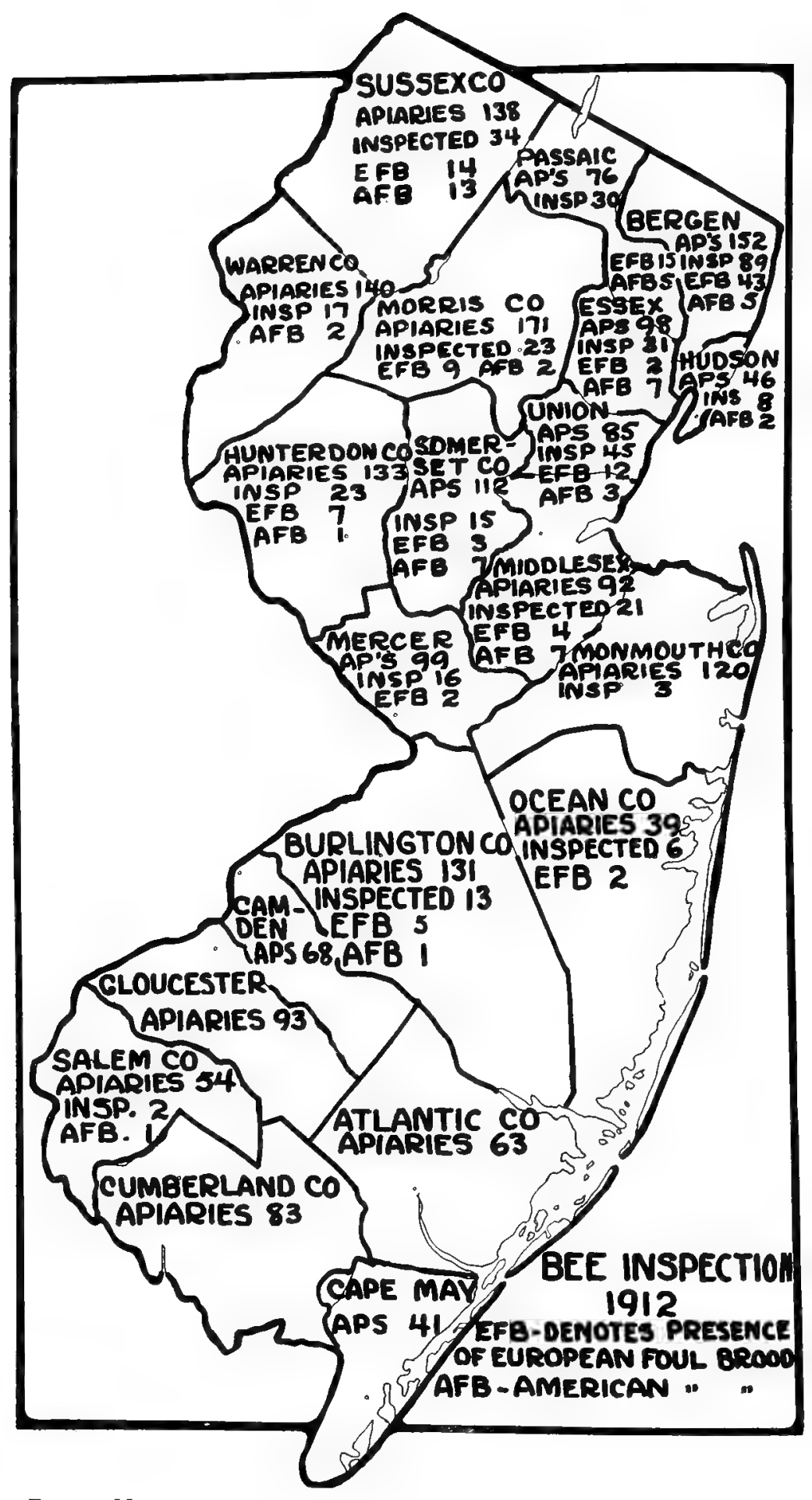




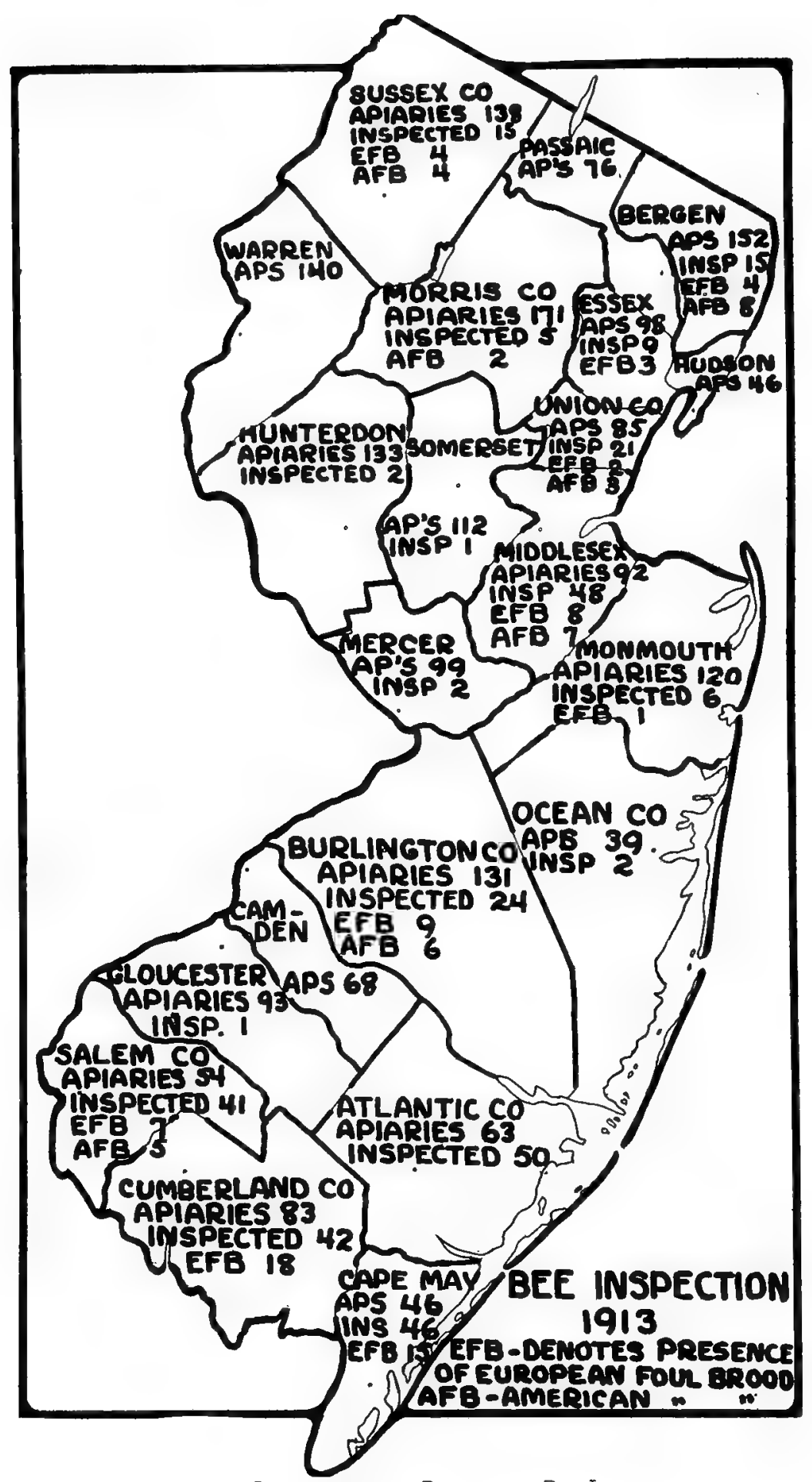

Fig. 3.-Map of New Jersey showing Results of Bee Inspection in igi3. 


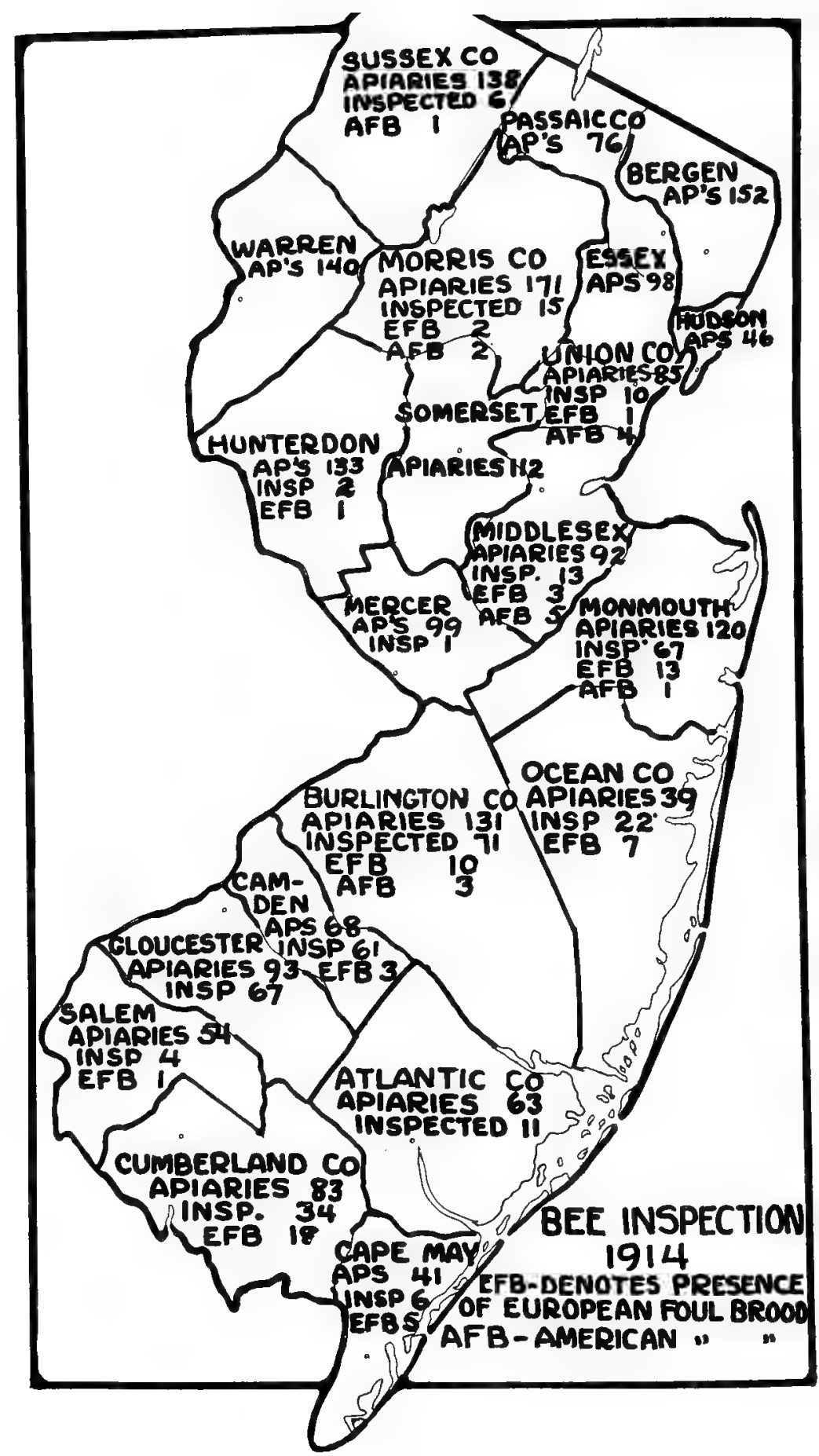

Fig. 4--Map of New Jersey showing Results of Bee Inspection in igi4. 


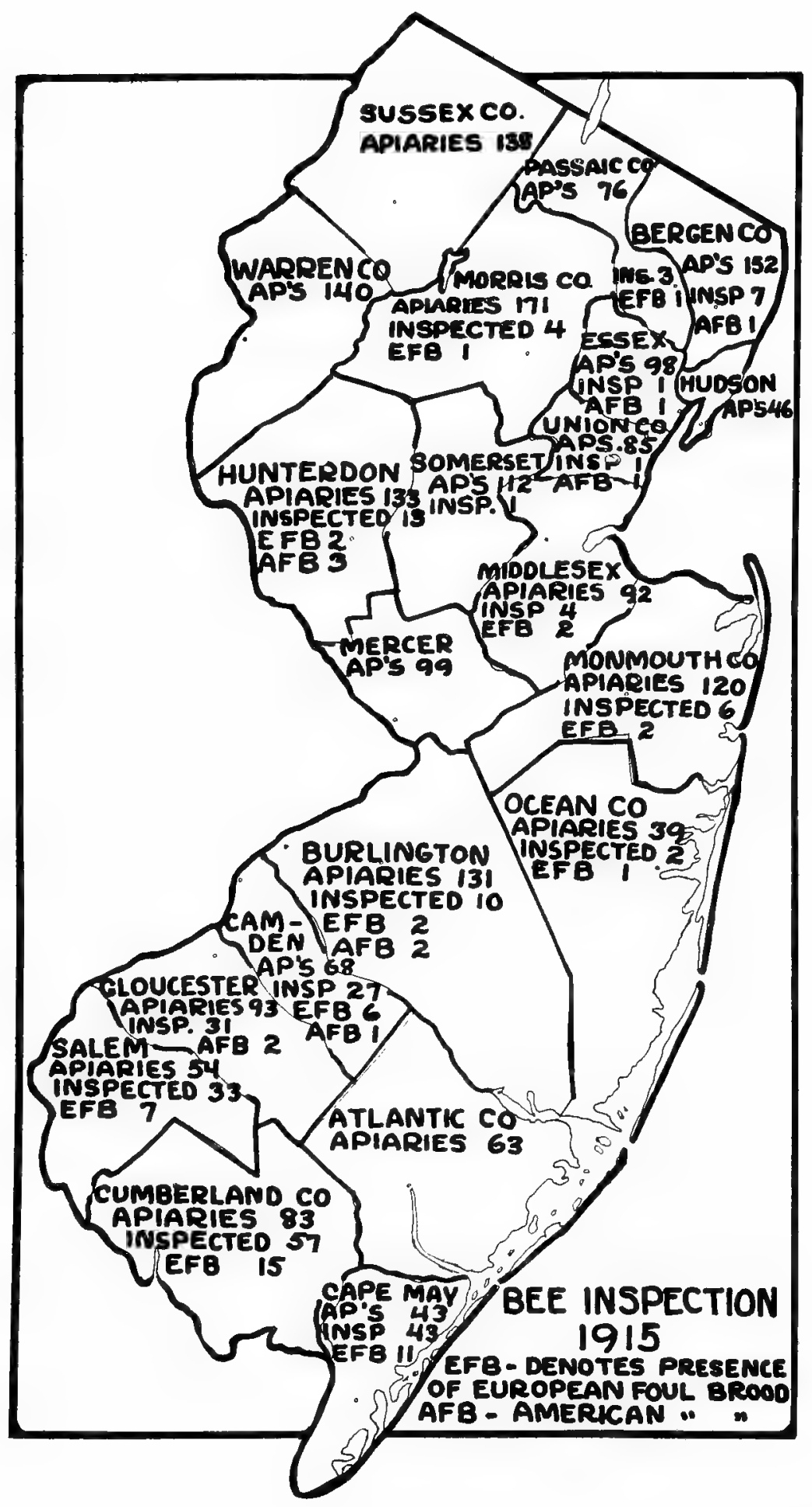

Fig. 5.-Map of New Jersey showing Results of BeE Inspection in igi5: 


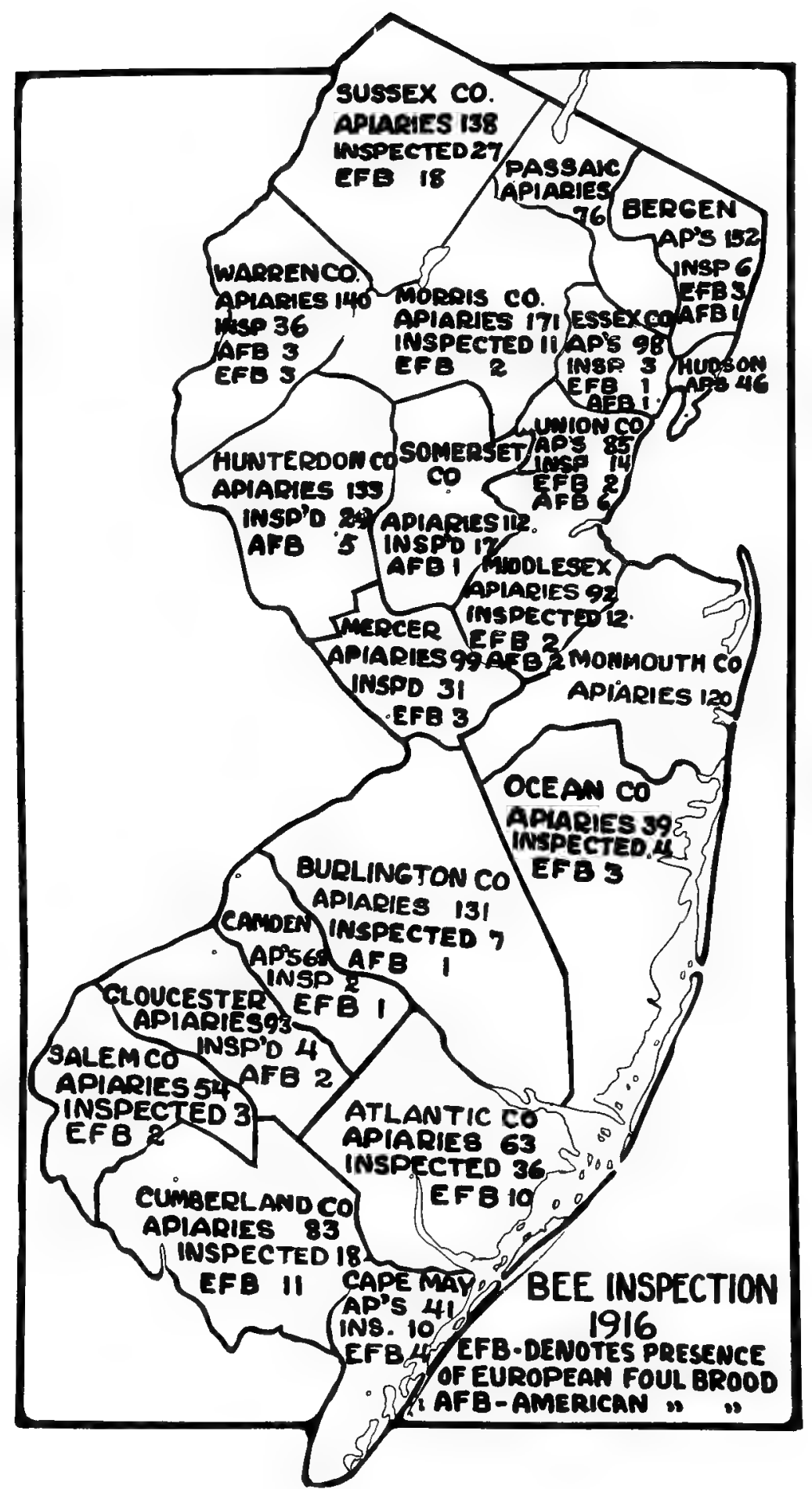

Fig. 6.- Map of New Jersey showing Results of Bee Inspection in igi6. 
At the beginning of 1913 it was decided to select a part of the State, thoroughly inspect it and reinspect to learn what the result would be. Because of their geographical location, Cape May, Cumberland and Salem Counties were chosen, as it.was believed that the danger of reinfection from outside sources was not great: Another inspection was made in 1915, and the results of these inspections are shown in Table II.

In 1913 European foulbrood was found in each of these three counties, and American foulbrood also appeared in Salem County. The number of apiaries in each county, although not large, was about the same. Salem led in the number of colonies. In Cape May County the percentage of both diseased apiaries and diseased colonies was greater than in either of the other two counties. In one apiary in Salem County both form of the disease were found. The combined figures for the three counties for the year show 34.I per cent of the I29 apiaries infected and I8.I per cent of the 836 colonies diseased.

In I9I 5 in this area no case of American foulbrood was found. The percentage of diseased apiaries in each county was reduced and the percentage of diseased colonies had dropped in each county. The greatest reduction both in diseased apiaries and diseased colonies is shown in Cape May County. Each county shows an increase in the number of colonies; the greatest, 57 per cent, is in Cape May County. The increase in Salem County is 45 per cent.

Taking the combined figures for the three counties, we see that there is a slight increase in the total number of apiaries. American foulbrood has entirely disappeared from the area, and the proportion of diseased apiaries is reduced to 25.9 per cent. The number of colonies increased from 836 to $\mathrm{I}, \mathrm{I} 36$, or a gain of 35.8 per cent. The reduction in the number of diseased colonies is more rapid than is true of the diseased apiaries, "the percentage in the whole area falling from I8.I per cent in 1913 to 6.2 per cent in 1915.

It is readily seen that in this, area three desirable changes have taken place. (1) American foulbrood has entirely disappeared. (2) European foulbrood has greatly decreased, and (3) the number of colonies of bees has increased. These are some of the tangible results of bee inspection-results which usually follow bee inspection. A fourth result, which is not shown in these figures and for which no definite data are at hand, is an increased honey crop due. 
first to the larger number of healthy colonies to gather nectar, and second, to the renewed courage of the beekeeper who gives the bees better attention.

Thorough inspection in any other part of the State will bring equally gratifying results; in fact, it is reasonable to suppose that because of the smaller number of box hives and box-hive beekeepers, better results could be secured in some other localities.

European foulbrood has been found in every county in the State except Gloucester and Hudson; and American foulbrood in all except Atlantic, Cape May, Mercer and Ocean. This indicates how widespread the disease has become, and the fact that there are upwards of 12,000 colonies of bees in the State gives some idea of the magnitude of the problem of disease control.

To get a correct idea of the amount of the disease in the State it would be necessary to inspect every colony of bees each year. However, from the data available from the work which has been done, a fairly reliable estimate of the amount and distribution of the disease can be had.

There are a considerable number of beekeepers who are progressive and who give their bees such attention that brood diseases are not likely to cause them any serious trouble. Their number is increasing at an encouraging rate.

The maps (fig. 2-6) show the approximate number of apiaries in each county, the number of apiaries inspected each year, the form of diseases found and the number of apiaries infected.

Some of the counties, it will be seen, have been quite thoroughly inspected. American foulbrood, it will be noticed, is, with one or two exceptions, confined to the upper half of the State, while European foulbrood is quite generally distributed over the whole State and is the form of disease which is threatening the beekeeping industry with extinction.

This is at the same time a disadvantage and an advantage-disadvantage because the action of European foulbrood is often so rapid that it soon kills all the bees belonging to the careless person; an advantage because the progressive beekeeper can control the disease without destroying the combs, and further, the introduction of good Italian queens is a large factor in its control.

It may be confidently stated that if every colony of bees in New Jersey should be furnished with a good Italian queen, European foulbrood would be reduced 75 per cent within a year. 


\section{Education}

Many who own bees have little or no knowledge of their care, and in order that they may do effective work in disease control it is necessary that they be taught both the identification of and treatment for diseases. Unless, therefore, much educational work is done in connection with bee inspection, bee disease control will not be entirely satisfactory.

The ideal condition is had when every beekeeper is thoroughly familiar with the symptoms of bee disease and with the latest approved method of control. Then disease can be treated upon its first appearance and it will not become epidemic.

The need of educating the beekeeper has been recognized from the beginning of inspection work in New Jersey, and it has been given considerable attention. During the past year, without in any degree relaxing the. efforts in inspection, emphasis has been placed upon the educational side of the work.

Efforts have been made toward reaching the beekeeper with better methods of management; (I) direct, (2) through the mails, and (3) through the farm demonstrators.

Educating the Beekeeper Direct.-When an apiary is visited, all conditions about the yard or hives which are not such that good financial results can reasonably be expected, are pointed out to the owner and remedial measures suggested. Highly important events in the cycle of the year-events which if properly controlled will result in success, and if neglected will cause failure-are discussed and the best practices in connection therewith are made known $t s$ the beekeeper.

Stress is laid on the money value of the honey crop from properly handled bees, also on the importance of correct manipulations at the proper time if a satisfactory crop is to be secured. The absolute necessity of proper management of swarming, the introduction of queens and proper supering are impressed upon the beekeeper.

Through the Mails.-During 1916 five circular letters were sent to the entire mailing list of about 2,000 beekeepers. These letters discussed "Building "up Colonies," "Swarm Control," "Supering," "Requeening," and "Wintering," and were sent when the information they contained would be timely. Many letters asking advice 
on bee management are received, and the best known practice in connection with the topic in question is given to the inquirer.

Through the Farm Demonstrators-Of all agencies at work carrying information to the farmer, it is evident that none is quite as effective as the farm demonstrator. His relations are more intimate with the farmer than is true of any other educational official. For this reason it was decided to add one more item to the already long list of duties with which the farm demonstrator is charged, and with him visit the farmer beekeepers.

The object of this was to give the farm demonstrator such information relative to beekeeping that he might be in a position to offer helpful advice to the farmer. Practically every farm activity except beekeeping is taught in the agricultural schools, and the farm demonstrators have had an opportunity to accumulate more or less information in every egricultural line except apiculture. Tours were made during 1916 with the farm demonstrators in Cape May, Cumberland, Atlantic, Burlington, Mercer and Sussex counties, and the interest of these men in the bees will surely be productive of good results.

Educational work is highly important, since it is evident that when the beekeeper is conversant with the best management of bees for profit the question of disease control will be largely solved.

The result of the educational effort is not easily shown in figures. Signs of progress, however, are noted in the changed attitude of beekeepers in some places from one of indifference or opposition to one of interest.

REQUIREMENTS AND POSSIBILITIES OF BEEKEEPING AS A BUSINESS

Requirements of Profitable Bee Husbandry

These are (I) the individual; (2) the location; (3) the bees, and all of which must be favorable if greatest success is to be attained.

There are four factors which influence profitable bee husbandry, (4) the apparatus. 


\section{The Individual}

In beekeeping. as in all other occupations, success depends upon the individual. Other factors enter into the problem to a considerable extent, but the individual can control the other factors and thus bring about success. To illustrate, should a given locality not be well adapted to profitable production because of a lack of nectar-secreting plants, or because the plants produce an inferior nectar, the beekeeper can change his base of operations. Should the ustal supply of nectar from early blooming plants fail, the beekeeper can move the bees to another location in time to meet a honey flow from later blooming plants. Should his stock of bees be below the average in productiveness, a change can be easily and quickly made.

It is readily seen then that any failure to secure profitable returns is usually directly traceable to the individual. There are no special qualifications necessary for success in beekeeping. An interest in the business and a willingness to give the bees every needed attention are the main requirements.

Manipulations with bees must be properly timed, thus promptness is necessary.

The successful beekeeper will not eagerly look forward to the close of the day's work; but will often consider the coming of darkness an undesirable interruption of his work. It is sometimes suggested that invalids may take up beekeeping. As an avocation this is true, but as a business it cannot be recommended for invalids.

\section{The Location}

Bees uninterfered with by man usually select some cavity for a home, and if its protection is insufficient to preserve them through the inactive season they perish. Likewise, if the amount of pasture within their reach is insufficient for their needs they perish. But when man undertakes the care of bees, due regard must be had to provide the conditions which will enable the bees not only to exist, but to accumulate the naximum amount of honey. The apiary should be located where the natural flora produces an abundance of nectar of high market value or where the farm crops usually grown are such that 
such nectar can be had from them. Planting for honey alone has not proven profitable. Since it is claimed that bees do not profitably go more than 2 miles for nectar, the apiary should be located so that abundant forage is within this distance.

The location of the apiary in relation to its exposure to prevailing cold winds is a matter which will make for or against success. The ideal situation is on a gently sloping hillside, protected by trees from the prevailing cold winds, and with a southern exposure.

Bees should not be located where they may prove troublesome to persons or animals passing.

\section{The Bees}

Variation in the productivity of honey bees is as great as in any other form of live stock. Several races of bees have been tried, but none as yet have proven as profitable as the Italians. There are a number of strains of these.

The apiarist should secure queens from a number of breeders with the best reputations, and from these select for propagating those which prove the most satisfactory. The honey producer has a better opportunity than the queen rearer to discover the good traits of his colonies.

\section{The Apparatus}

New and complicated apparatus is constantly being offered to the beekeeping public, much of which is of little or no use to the practical honey producer. The simplest apparatus will be found the most satisfactory.

The majority of successful honey producers are using a dovetailed hive with Hoffman frames and telescoping cover. For comb-honey production the tendency in New Jersey is to use a tall section measuring $4 \times 5 \times \mathrm{I} 3 / 8$ inches. The $4 \frac{\mathrm{T}}{4} \times 4^{\mathrm{I} / 4} \times \mathrm{x} \mathrm{I} / 2$-inch plain section also is used somewhat. There is not enough difference in these styles of sections either as rgards the behavior of the bees toward them or their appeal to the honey purchasr, to decide which is better. It has been contended that the tall section is more attractive to the prospective customer because it presents a large comb surface to the eye, but this has not been 


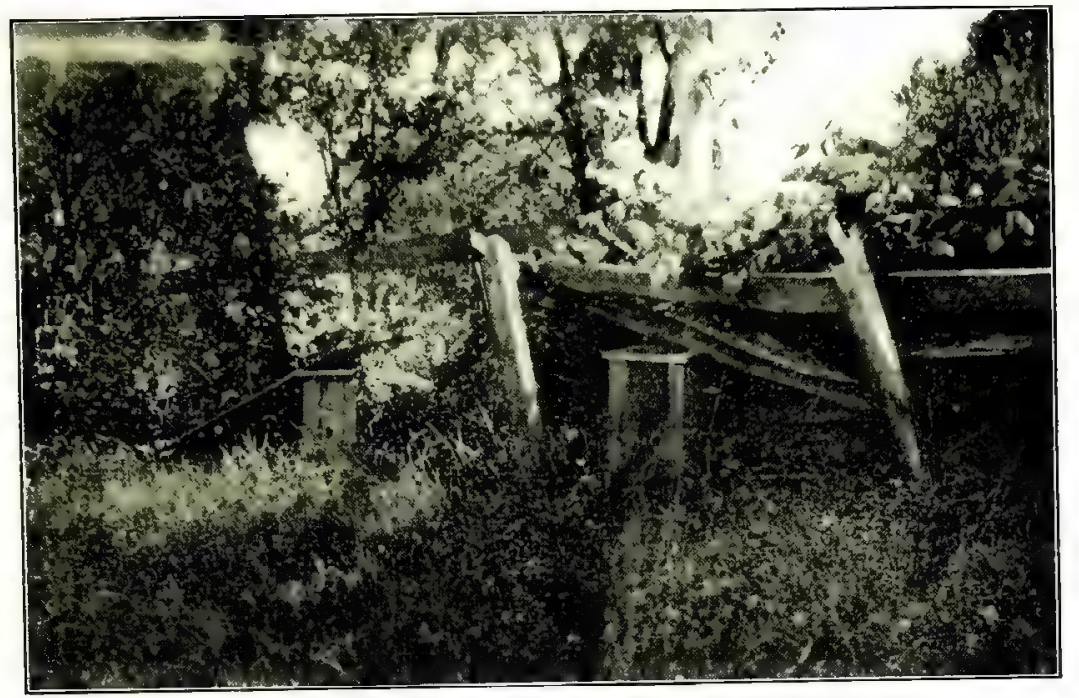

Fig, 7.-The OWNFr OF THIS Type OF Apiary in NeW Jersey finds that BeEkeping Does Not Pay.

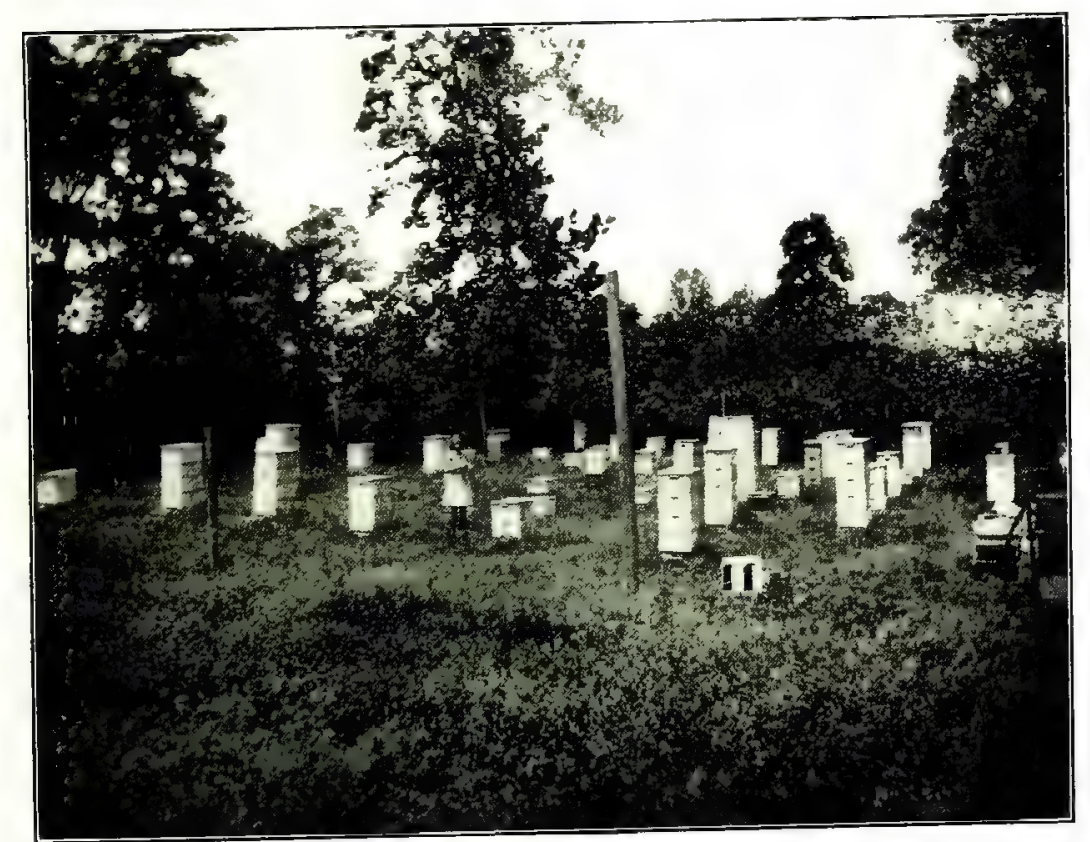

Fig. 8.-The Annual Returns from this New Jersey Apiary are ENTIRELY SATISFACTORY. 


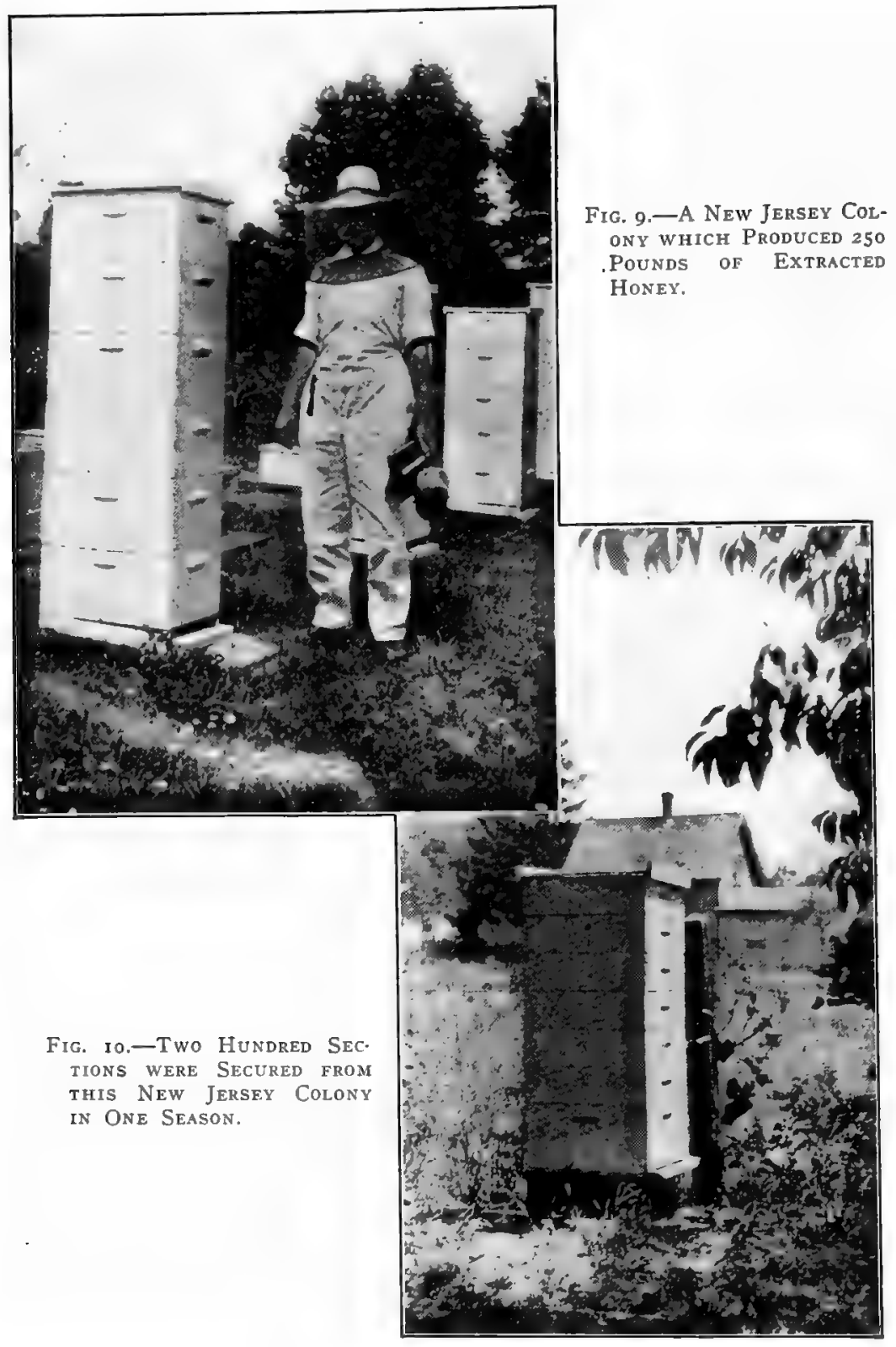




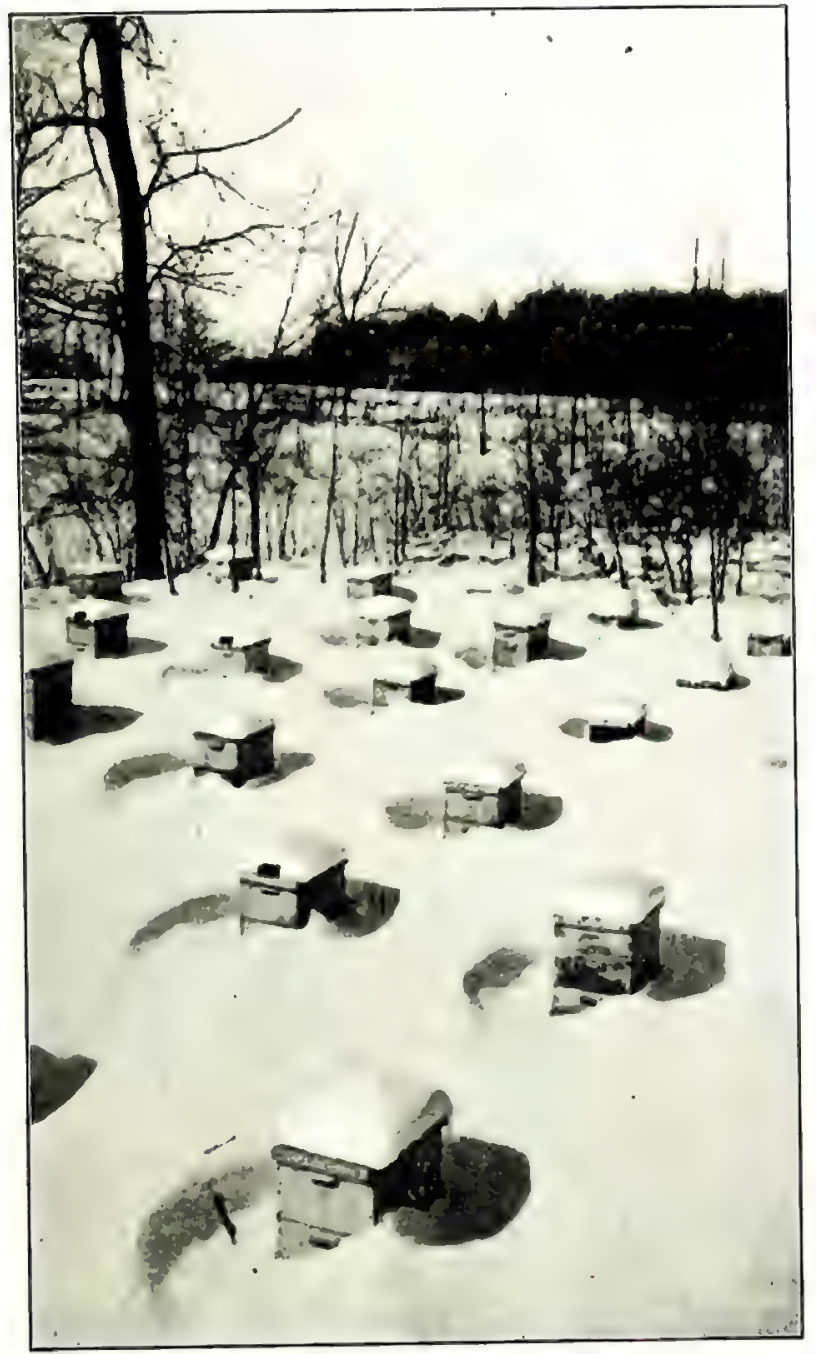

Fig. II.-Unfortunately, Many Apiaries are Obliged to Pass Through the Winter with no more Protecton than is Given this New Jersey Apiary. 


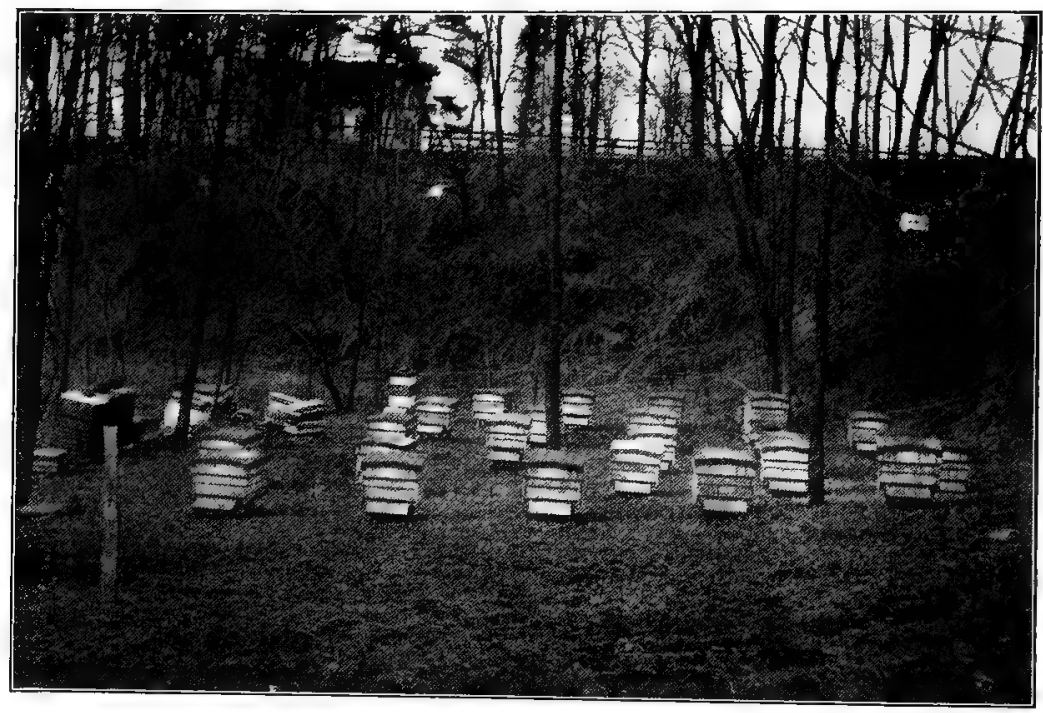

Fig. I 2.-A New Jersey Apiary Provided with Winter Cases Which Give Ample Protection against Low Temperatures. 
proven. For extracted honey production practically all New Jersey beekeepers use the Hoffman frame.

Apparatus such as swarm catchers, queen and drone traps, and many types of feeders on the market, have no place in a successful honey-producing apiary.

In selecting apparatus it is well to consider some form of winter protection for the bees more than is provided by the single-walled hives.

\section{Returns from Beekeeping}

\section{Financial}

The amount of money to be made from a business is often the main consideration. The opportunities to amass wealth in any rural occupation are rare indeed. There are, however, greater and quicker returns in beekeeping, considering the amount of time and capital invested, than in any other rural occupation. Many times the beekeeper receives for one season's crop an amount equal to his total investment. It is, of course, too much to expect this to occur every year. As is true of every other rural business, there are seasons when the returns are small. Rare, indeed, is it necessary in New Jersey to feed the bees to keep them alive. Judging from personal experience and the data which have been secured in the past five years' inspection work in the State, a gross return of $\$ 5$ a colony per year is a conservative estimate if the honey is sold at wholesale. Should the beekeeper be-able to retail his honey (and this is desirable), 50 per cent could be added to these figures.

An average of 35 sections of comb honey, or 60 pounds of extracted honey, per colony is common. Individual cases of 250 pounds of extracted and 200 sections of comb honey from a hive have been secured.

A few instances of what has been accomplished in New Jersey with bees will give some idea of the financial possibilities of beekeeping in this State. The person operating the largest number of colonies in the State has but 250. His investment he estimates at $\$ 2,500$. About one-third of the bees are operated for comb honey and the remainder for extracted. No help is hired 
at any time. The crop one year was 18,000 pounds of honey, both comb and extracted. This was sold so that the net price received was 12 cents per pound. After deducting Io per cent for interest and depreciation on the investment, the beekeeper received $\$ 1,910$ for his labor, which in all did not exceed 7 months of the year. It might not be out of place to point out here that this beekeeper is much past the prime of life, is not rugged in health and took up beekeeping after business cares had compelled him to abandon another business. Five hundred colonies in 5 yards can be operated by one active person. And by using in selling the honey that period of the year when the bees do not need attention, an amount per colony equal to that secured by the above-mentioned beekeeper can be realized, or $\$ 3,500$ to $\$ 3,700$ per year.

One apiary during the season of I9I6 was increased from 45 to 90 colonies and 4,000 pounds of extracted honey secured. The wholesale cash value of the crop was $\$ 320$.

An apiary of 96 colonies yielded one year 7,000 pounds of extracted honey, worth wholesale $\$ 490$. Another of 8 colonies was increased to 16 and $\$ 100$ received for the crop of honey. Another of 7 colonies was increased to I 5 and a cash return of $\$ 96$ secured. Three thousand pounds of extracted honey sold at $\$ 240$ is the record for an apiary of 23 colonies which was increased to 32. An average crop of 50 pounds of honey, both comb and extracted, has been secured for the past 5 years from an apiary of 50 colonies. The wholesale value of the crop was $\$ 375$. In another case the beekeeper of 5 colonies did not see the bees between June Io and September I5, yet the crop was 460 sections, worth wholesale $\$ 69$, or $\$ 13.80$ per colony. In another case an apiary of 32 colonies yielded 3,600 pounds of extracted honey, which was sold at a farmers' market, and I 8 cents per pound realized, or $\$ 648$.

In each of these cases except the first, it is readily seen that the number of colonies is so small that anything like a fair estimate of the time and labor involved is difficult. In all probability, in each case the time used was that which otherwise would have been wasted. 


\section{Healthful}

There are practically no conditions about beekeeping which would injure the health of the person following the business, unless the stings might be considered unhealthful. Since, however, they can be almost entirely prevented and their effect is so easily overcome, they need not be considered.

Much of the work is out-of-doors in the most pleasant time of the year, and there is no occasion for exposure to harmful weather.

It is a mistake, however, to consider beekeeping as a business well suited to the invalid in body or mind, since such is not the case. Considerable manual labor is necessary for best results, some of which is rather strenuous. The problems presented by the ever-changing seasons are such as will sometimes puzzle the most active brain. Nevertheless, beekeeping can be and is followed by persons well advanced in years. One of the most successful beekeepers in the United States today has passed his eightieth birthday. But he has in his long experience learned to get maximum results with a minimum amount of labor.

\section{Pleasure}

To the person really interested in the work, beekeeping affords boundless pleasure. Bountiful crops of honey, of course, increase the pleasure.

Practically no two seasons in the bee yard are alike, hence the work always presents new and interesting problems, and thus there is no opportunity for pleasure to wane through monotony or sameness of the work. The problems of beekeeping lead the apiarist into so many branches of investigation that his interest is continually held. His problems bring him into close contact with the great out-of-doors.

Not the least among the pleasures of beekeeping is that which comes from a knowledge that the beekeeper is gathering a healthful food which would otherwise go to waste, and therefore he is a benefactor to mankind. Also, at the same time that the bees are gathering this healthful food they are carrying pollen from flower to flower, causing a greater production of fruits and seeds and thus further benefitting the human family. 
When one becomes thoroughly familiar with the bees' activities, the work can be so arranged that the beekeeper can be absent from the bees for a considerable length of time, even in the summer, without detriment to the bees. Thus it will be seen that there is a certain flexibility to the work, and that there is not the feeling of bondage which attends the management of many forms of live stock which demand attention every day in the year.

\section{Opportunities for Profitable beekeeping in New Jersey}

The conditions within and the location of New Jersey make its beekeeping opportunities quite unique.

First, the dairying interests in the State are extensive and because much of the soil within the State is lacking in lime, alsike clover is much grown for the cattle and the acreage of this plant is annually increasing. Alsike clover will grow on acid soil where other clovers would fail. The quality of honey from alsike clover is such that only experts can distinguish it from that gathered from white clover, and it is well known that white clover honey brings the highest market price. The yield of nectar from alsike clover is heavy and extends over a considerable period of time, ustrally 6 weeks at least.

Alsike clover, however, must not be considered to be the only important nectar-secreting plant. Locust is also important. White clover contributes its share to the beekeeper's profits. Tulip, poplar, sunac, golden rod, aster and buckwheat also help to make the crops satisfactory. Besides these, there is an almost innumerable array of trees and plants which furnish more or less nectar for building up the colonies to maximum strength as well as to help swell the surplus crop.

Second, the climate of the State is such that only the grossest neglect of the bees will result in any considerable colony loss during the winter. This is particularly true of the lower two-thirds of the State, but this must not be construed as an endorsement of such shiftless wintering arrangements as poor hives and no extra protection against low winter temperatures. It does show, however, that with ordinary care there need be no winter loss whatever.

The flora of the State is so varied that when one plant which usually furnishes nectar for one reason or another fails to do its 
duty, there is usually one or more which do produce well, thus tiding over the period of dearth of nectar from the usual producer.

Seldom, indeed, is it necessary to feed the bees to tide them over a poor season, unless the beekeeper has neglected the bees and allowed them to swarm excessively or has unwisely manipulated them. The opportunity to have apiaries in scattered locations is good because of the many good roads in the State. Thus apiaries 20 miles apart offer no transportation difficulties whatever.

If a beekeeper only produces honey he will have about 6 months of the year of unemployment, hence it is desirable that some profitable work be had through the season when the bees do not need attention. New Jersey offers a splendid opportunity to the beekeeper to spend this period of the year in selling his crop, because the many manufacturing centres are all excellent markets for honey and the good roads put them within driving distance by automobile. By retailing his crop the beekeeper can double his income. By selling to retailers 50 per cent will be added to the income.

Should there be good reasons why the beekeeper should not retail his crop or even sell to retailers, the New Jersey beekeeper still has a marked advantage because he is within a short distance of New York, which is the best wholesale honey market in the East.

\section{Overstocking}

There is estimated to be about 12,000 colonies of bees in the State. Probably two-thirds of these are in the northern half, and yet in this part the number could be doubled and all would find ample pasture. In the southern half, and where there is excellent forage for bees, there are whole townships with less than 25 colonies. These same townships would profitably support 200 or more colonies.

\section{Markets for the Increased Crops}

Lest anyone should fear that there would not be a ready market for the honey if the number of colonies is doubled and the annual output from each hive increased to 35 pounds, it should be borne in mind that tons of honey are annually brought into this State to supply the local demand. Some of this honey comes from points as far distant as Colorado. Further, there has been no concerted movement in New Jersey to popularize honey as a food. It may 
be safely stated that the present consumption of honey in New Jersey could easily be increased tenfold by a judicious advertising campaign.

It would be folly to estimate the amount of nectar annually wasting in New Jersey because of insufficient bees and beekeepers to gather it. The figures would be so large that no one would credit them. It is very sure, however, that with proper management the bees already in the State would annually produce 35,000 dollars' worth more honey than is now being received from them.

Doubling the number of colonies in the State and giving them all proper care would result in an increased annual income to the beekeepers of the State of $\$ 85,000$. This amount, it would seem, is worth while securing, more particularly so since no effort is required by anyone to produce the crop-all that is needed is to gather it.

Some attempt can be made to compute the value of the nectar which the bees would gather, but the value of the service which they perform as pollenizers cannot be computed. It has been estimated to be even more than the value of the honey and wax secured. Certain it is, however, that the increasing orcharding in the State will create a demand for more honey-bees as pollenizers. In fact, one orchardist has offered $\$$ IOO for the use of roo colonies for about to days, or during the blossoming period of the fruit trees.

\section{Beekeeping Literature}

Many of the beekeepers of New Jersey rely entirely too muck: on folklore in the management of their bees. Such practices as "drumming" to "settle" a swarm, or "telling the bees" when a member of the family dies to ward off ill-luck, or refusing to sell bees for fear of "selling their luck" cannot result in profitable beekeeping. There are causes for all bee activities, and in order that he may direct this activity so that it will result in giving him the greatest profit, the beekeeper needs to learn as much as possible of the causes which underlie these activities.

Satisfactory results will be had when the beekeeper prevents entirely, or at least controls, swarming rather than trusting to some such incantations as "drumming" and "tanging" to prevent swarms from leaving. 
If, instead of "telling the bees" when the caretaker dies, some other person gives them proper care, "bad luck" will have no effect on the bees.

Every beekeeper should have at least one good book on bee culture; more would be better that his views be not too much influenced by a single writer. At least one bee journal should come regularly to the person who hopes to get satisfactory results from his bees.

Publications Pertaining to Beekeeping Issued By the United States Government

Through its corps of trained investigators the United States Government is constantly issuing circulars and bulletins containing information invaluable to the beekeeper. Many of these can be had upon request; for some a small charge is made. For the convenience of the beekeeper a list follows, and it is urged that each one secure the entire list.

The bulletins named below may be had free by applying to the congressman of your district at Washington, D. C.

Farmers' Bulletin No. 442, The Treatment of Bee Diseases.

$\begin{array}{llll}\text { " } & \text { " } & 4 & 447, \text { Bees. } \\ \text { " } & \text { " } & 503, \text { Comb Honey. } \\ \text { " } & 4 & 487, \text { Sweet Clover. } \\ & \text { " } & 653, \text { Honey and its Uses in the Home. }\end{array}$

The publications in the following list may be obtained from the Superintendent of Documents at the prices indicated. Remittances should be made to the Superintendent of Documents, Government Printing Office, Washington, D. C., by postal money order, express order or New York draft. If currency is sent, it will be at sender's risk. Postage stamps, defaced or worn coins, foreign coins and uncertified checks will not be accepted. 
Bur. Ent. Bul. 55, Rearing of Queen Bees................5c

" " "70, Report of Meeting of Inspectors of Apiaries,

San Antonio, Texas, Nov. 12, 1906.........15c

" " "75, Part I, Production and Care of Extracted Honey. . be

" " " 75, Part II, Wax Moths and American Foul Brood.. 5c

" " "75, Part III, Bee Diseases in Massachusetts....... 5c

" " "75, Part IV, Relation of Etiology (Cause) of Bee

Disease to Treatment............... $5 \mathrm{c}$

" " "75, Part V, Brief Survey of Hawaiian Bee Keeping..16c

" " "75, Part VI, Status of Apiculture in United States. . 5c

" " " $" 75$, Part VII, Bee Keeping in Massachusetts........ 5c

" " " $" 75$, Part I-VII, Complete with Contents and Index...30c

" " " $" 98$, Historical Notes on Causes of Bee Diseases.....10c

" " " $" 121$, Behavior of Honey Bee in Pollen Collecting......5c

" "Cir. 138, Occurrence of Bee Diseases in United States.... 5c

" " " $"$ "157, Cause of European Foul Brood............ 5c

" " " "161, Manipulation of Wax Scales of Honey Bee..... 5c

" " "169, Sacbrood, a Disease of Bees..............5c

" "Tech. Series 19, Anatomy of Honey Bee................20c

U. S. Dept. Agr. Bul. 92, Destruction of Germs of Infectious Bee

Diseases by Heating............ 5c

" " " "93, Temperature of Honey-bee Cluster in

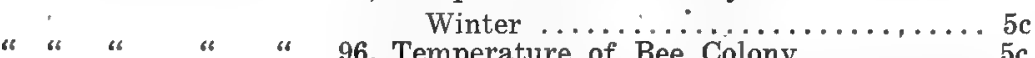

" " "325, Honeybees: Wintering, Yields, Imports and Exports of Honey........... 5c 


Photomount

Pamphlet

Binder

Gaylord Bros., Ine.

Makers

Syracuse, N. Y.

PAT. JAM 21, 1908 


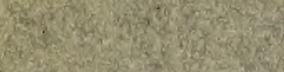

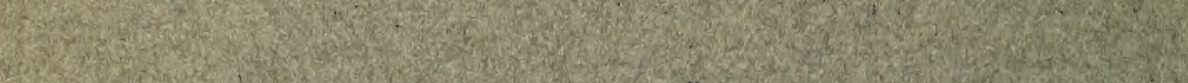

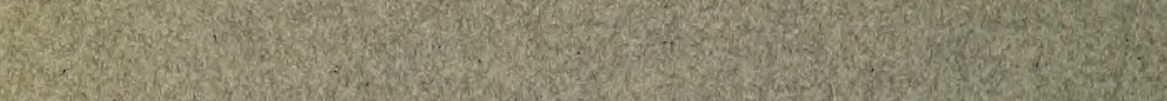

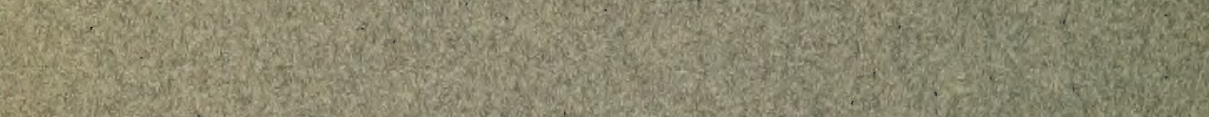

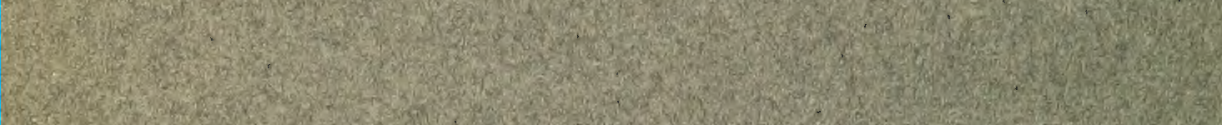
5
4 W.

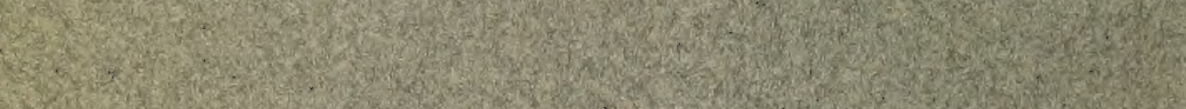

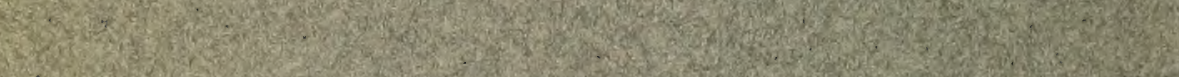
-

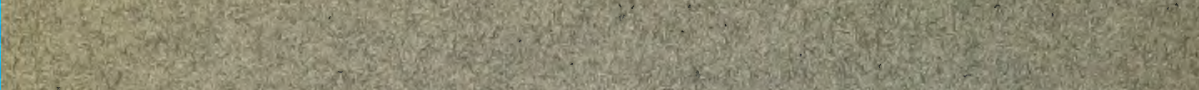

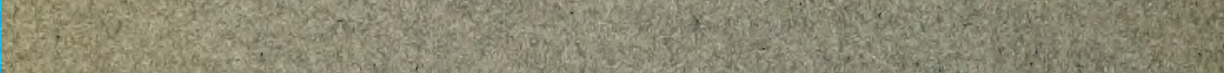

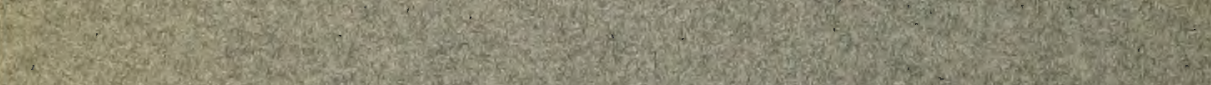

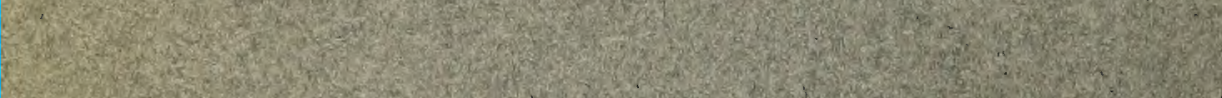

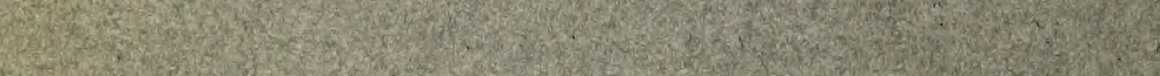
C.

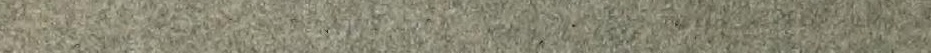

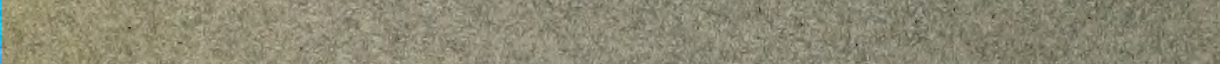

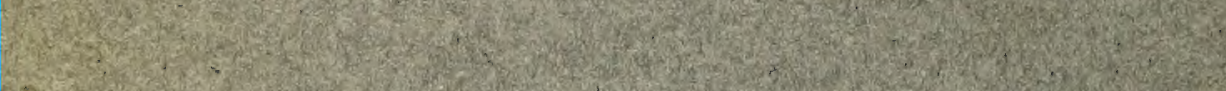
-

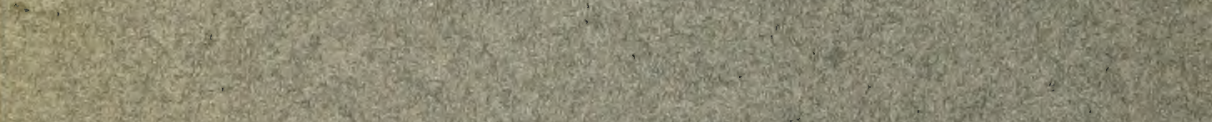

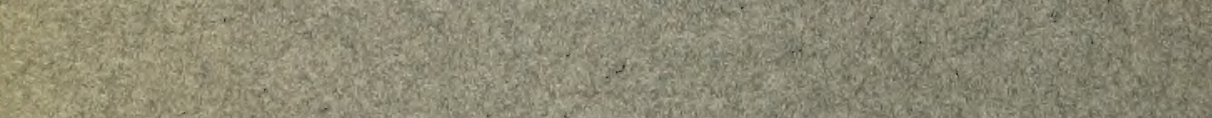
2.

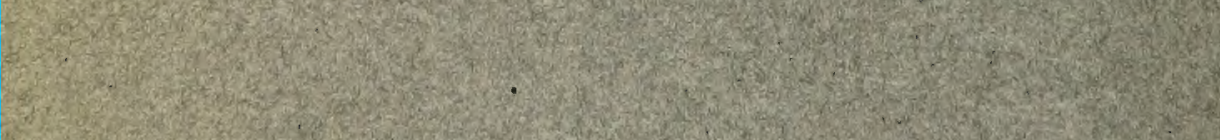
W. (3)

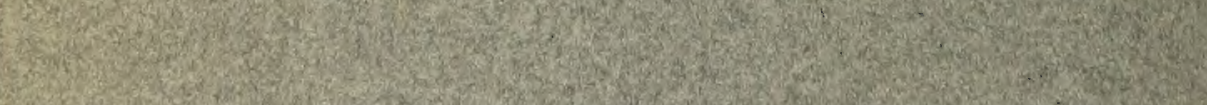

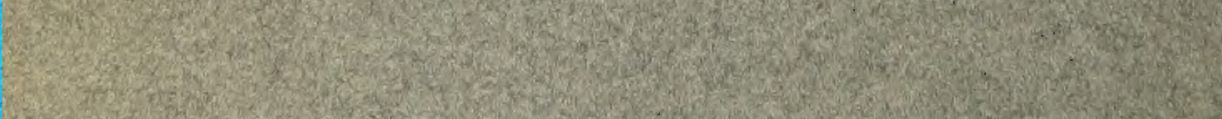

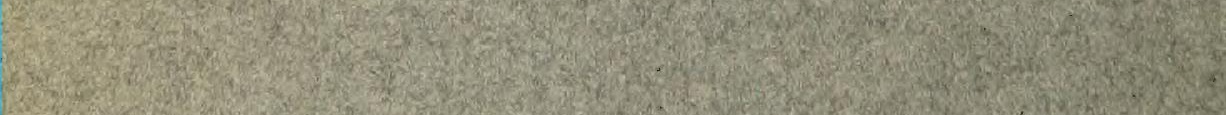
W.

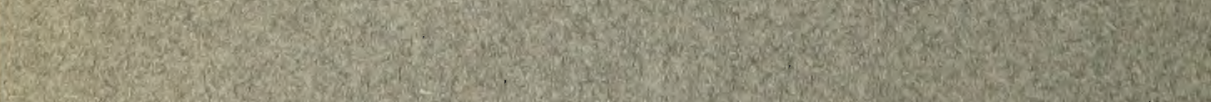

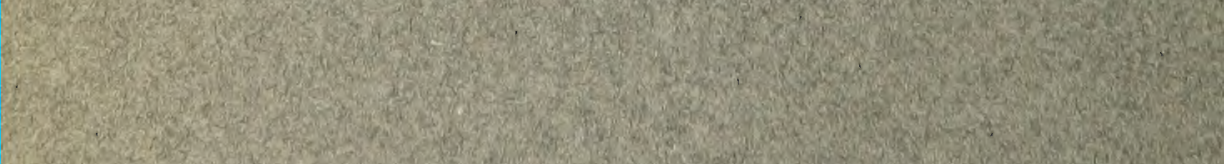
(4) 